\title{
THE RELATION OF SPECIFIC GRAVITY TO COMPOSITION AND TOTAL SOLIDS IN NORMAL HUMAN URINE ${ }^{1}$
}

\author{
By J. WAIDE PRICE, MAX MILlER, ANd J. M. HAYMAN, JR. \\ (From the Department of Medicine, Western Reserve University, and the Lakeside Hospital, \\ Cleveland)
}

(Received for publication February 5, 1940)

A study of the specific gravity of urine can make no pretense to novelty. The superiority of specific gravity determinations to uroscopy was pointed out by Cardinal Nicolaus of Cusa (Cusanus) in 1440. Leonhard Thurneysser of Thurin, physician to Johann Georg von Brandenburg, estimated the specific gravity of urine with a crude pyknometer (1576) and Methe (1727) devised a urinometer much like those in use today (13). The systematic study of the density of urine in kidney disease was described by Blackall in 1820 (6) who suggested that a low specific gravity might be due to a deficiency of urea in the urine. Bright and his associates (9), as well as Christison (10), Rayer (38), and Rees (39), gave increasing emphasis to its importance as an indication of the loss of concentrating power of the kidney. Hedinger and Schlayer (23) attempted to standardize conditions in order to obtain a urine of maximum concentration. Mosenthal (33), Volhard (42), Addis and Shevky (2), Lashmet and Newburgh (28), and Fishberg (14) introduced various modifications designed to simplify and increase the reliability of the concentration test. Fishberg, especially, has emphasized its clinical value, designating it as "the most generally useful test of renal function for the general practitioner."

Many attempts have been made to estimate total solids of urine from specific gravity. All such efforts to discover an exact simple relationship presuppose either that each of the solids has the same effect per unit concentration, or that the composition of the urine is always the same. Long (29) and Albarran (3), however, pointed out the markedly different effects on specific gravity of equal concentrations (by weight) of the principal constituents of urine. Blohm (7) and Addis and Foster (1) concluded that no precise quantitative significance could be attached to the results of any method of estimating total solids of the urine from

\footnotetext{
${ }^{1}$ Supported by a grant from the Commonwealth Fund.
}

specific gravity measurements because of its variable composition.

Pepper (35) found that, in normal subjects, urea and chloride accounted for 50 to 75 per cent of the specific gravity of the urine, but that the ratio of urea to chloride might vary considerably. Similar studies by Ishizu (24) on Japanese substantiated these findings. Alving and Van Slyke (4), on the basis of theoretical calculations without actual determination of the individual constituents in a given urine, postulated that "threefourths of the rise in specific gravity above that of water may ordinarily be attributed to the mineral salts, and about one-fourth to urea, with other organic solids of relatively slight influence." This statement was made in regard to urines of high gravity. Urines of low gravity were explained as being attributable in some cases to polyuria, in others to a low output of salts. This emphasis on the gravity contribution of salts led these authors to conclude that the concentration test appears to measure chiefly the ability of the kidney to concentrate mineral salts.

Weiser and Thelen (43), on the other hand, believed that the constituents of the urine could not alone account for the specific gravity and that volume effects or other physico-chemical phenomena would have to be invoked in order to account for the "residual specific gravity" (gravity unaccounted for by known constituents). Their work raises an important question. Is it necessary to postulate physico-chemical or other effects to explain the total urinary specific gravity, or is the gravity of any urine a simple additive function of the concentrations of its constituents? If the latter is correct, then it should be possible to calculate the specific gravity of a urine from its composition.

This study concerns the relationship of the specific gravity to the composition of urine in normal subjects. It attempts to provide an answer to the following questions. Can the specific gravity of 
a complex dilute solution of inorganic and organic substances be calculated with accuracy? Can the specific gravity of a normal urine be similarly calculated from analysis of its composition? Is specific gravity a satisfactory index of total solids?

\section{Specific gravity of complex aqueous solutions as an additive property of the contributions of the individual components}

When a solid is dissolved in water, a slight increase in volume occurs, but the weight of water displaced is much less than the weight of the solute entering into the homogeneous liquid phase, so that the resulting solution has a greater weight per unit volume than the water alone. The mass per unit volume either of the solvent or of the solution is defined as the absolute density. Generally, however, the term "density" refers to the relative density, i.e., to the ratio of the density of the solution to the density of a standard (usually water) either at the same temperature $\left(D \frac{t^{\circ}}{t^{\circ}}\right)$ or, more frequently, at $4^{\circ}\left(D \frac{t^{\circ}}{4^{\circ}}\right)$. In either case, the value obtained is commonly called the specific gravity. $D \frac{t^{\circ}}{4^{\circ}}$ is the preferable value since it is numerically equal to the density at $t^{\circ}$, i.e., it is the weight in grams per cubic centimeter at $t^{\circ}$ centigrade.

Since the terms "density" and "specific grav-

TABLE I

\section{Specific gravity factors}

Values to be added to the specific gravity of water at $\frac{20^{\circ}}{4^{\circ}}$ $(0.99823)$ to give the specific gravity at $\frac{20^{\circ}}{4^{\circ}}$ of a 100 milliequivalent (or milli-molar) solution of the principal solutes found in urine.

\begin{tabular}{|c|c|c|c|c|c|c|c|c|}
\hline & \multicolumn{6}{|c|}{ Increment per $100 \mathrm{mEq}$. per liter } & \multicolumn{2}{|c|}{$\begin{array}{l}\text { Inerement per } \\
100 \mathrm{mM} . \\
\text { per liter }\end{array}$} \\
\hline & Cl & SO4 & $\mathrm{H}_{2} \mathrm{PO}_{4}$ & HPO, & $\mathrm{HCO}_{3}$ & $\mathrm{C}_{2} \mathrm{H}_{5} \mathrm{O}_{2}$ & $\begin{array}{l}\text { Creas- } \\
\text { tinine }\end{array}$ & Urea \\
\hline \multirow[t]{2}{*}{$\begin{array}{l}\mathrm{Na} \\
\mathbf{K} \\
\mathrm{NH}_{4} \\
\mathrm{Cg}_{\mathbf{g}} \\
\mathbf{M g}_{\mathbf{g}}\end{array}$} & $\begin{array}{l}0.00413 \\
0.00475 \\
0.00166 \\
0.00454 \\
0.00385\end{array}$ & $\begin{array}{l}0.00642 \\
0.00700 \\
0.00388 \\
0.00668 \\
0.00603\end{array}$ & $\begin{array}{l}0.00894^{*} \\
0.00965^{*} \\
0.00754 \\
0.00880\end{array}$ & \begin{tabular}{|l|}
$0.00675^{\circ}$ \\
$0.00714^{\circ}$ \\
0.00349
\end{tabular} & $\begin{array}{l}0.00610 \\
0.00668\end{array}$ & 0.00417 & \multirow[b]{2}{*}{$0.00285^{*}$} & \multirow[b]{2}{*}{0.00162} \\
\hline & & & & & & & & \\
\hline
\end{tabular}

* Determined experimentally. Other values calculated from density data of Landoldt-Börnstein and International Critical Tables. ity " are frequently rather loosely used, it should be emphasized that determinations of specific gravity are of no value unless the conditions under which they were obtained are recorded.

In the following discussion, the portion of specific gravity of a solution above the density of water similarly determined has been defined as the specific gravity increment. For water, $D \frac{t^{\circ}}{t^{\circ}}$ is unity and $D \frac{t^{\circ}}{4^{\circ}}$ is the density at $t^{\circ}$. Thus for an aqueous solution, $D \frac{t^{\circ}}{t^{\circ}}-1$ or $D \frac{t^{\circ}}{4^{\circ}}-d_{t}$ (where $d_{t}$ is the density of water at $t^{\circ}$ ) gives the specific gravity increment. To be strictly comparable, since $D \frac{t^{\circ}}{4^{\circ}}=D \frac{t^{\circ}}{t^{\circ}} \times d_{t}$, the specific gravity increment of a solution of gravity $D \frac{t^{\circ}}{4^{\circ}}$ should be given by $\frac{D \frac{t^{\circ}}{4^{\circ}}}{d_{t}}-1$. Rearranging this expression to $\frac{D \frac{t^{\circ}}{4^{\circ}}-d_{t}}{d_{t}}$ shows that, since the numerator is small and the denominator approximately unity, the absolute error introduced by using the simpler expression is slight. In this study, $D \frac{20^{\circ}}{4^{\circ}}$ is determined to the fourth decimal place and the above simplification affects the fifth decimal by less than five units, so the expression $D \frac{20^{\circ}}{4^{\circ}}-0.9982$ has been used to determine the specific gravity increments.

Before studying the relationship between specific gravity and concentration of solutes in aqueous solutions containing more than one dissolved substance, the effects of the individual solutes were investigated.

From the density tables of Landoldt-Börnstein's Tabellen and the International Critical Tables the specific gravity increments of solutions containing 100 milli-equivalents (or milli mols) per liter at $20^{\circ}$ were calculated, expressing the specific gravity as $D \frac{20^{\circ}}{4^{\circ}}$. When the necessary data were not available or recorded values did not agree, the increments were determined experimentally, using pyknometers of approximately $10 \mathrm{cc}$. capacity. Since the error in the determination of specific gravity is less than 0.0001 , the factors may be in error in the fifth decimal place but probably are all 
accurate to the fourth place. They are recorded in Table I.

Since specific gravity increment varies directly with concentration in the lower concentration ranges, the values in Table I may be used to calculate the specific gravity of a solution of any of the above substances in the concentration range found in urine (from 20 to $300 \mathrm{mEq}$. per liter for the inorganic constituents and from 100 to $600 \mathrm{mM}$. per liter for urea). Thus, specific gravity $\frac{20^{\circ}}{4^{\circ}}$ of 1 per cent $\mathrm{NaCl}(171.2 \mathrm{mEq}$. per liter $)=0.99823$ $+(1.712 \times 0.00413)=1.00529$. The fifth decimal figure is significant only in placing the fourth figure to the closest unit.

Albarran's data (3) were derived in a like manner but calculated as grams of substance necessary to elevate the specific gravity 0.001 at $15^{\circ} \mathrm{C}$. when added to a liter of urine. Others (Addis and Foster (1), Pepper (35), Alving and Van Slyke (4), Ishizu (24), Willis (44), Weiser and Thelen (43), etc.) have made similar calculations.

In applying these factors to the calculation of the specific gravity of a strong solution or of a solution containing more than one solute, the total concentration of solute becomes the limiting factor in the accuracy of the calculation. Thus, each factor in the above table is calculated to allow for the displacement of a certain volume of water by the molecules of the solute when the latter is present in relatively low concentrations ( 1 to 2 per cent). If this concentration is sufficiently increased, or if other solutes are added, the volume of water in one liter of solution becomes progressively less and errors of increasing magnitude appear. In the case of $\mathrm{NaCl}$, the calculated specific gravity is in error by about 0.0004 at 4 per cent and 0.0010 at 6 per cent concentration. These values, however, are well above the concentrations of $\mathrm{NaCl}$ found in urine. The calculated specific gravity of a 6 per cent urea solution is in error by about 0.0001 . From a similar consideration of the other factors above, it may be estimated that the error in calculating the specific gravity contribution of a single substance in urine is 0.0001 or less. The use of factors based on molar rather than molal concentration eliminates the necessity of determining water content in each analysis.

Two implications are involved in applying simi-
TABLE II

Calculated and observed specific gravities at $\frac{20^{\circ}}{4^{\circ}}$ of an

"artificial urine"

\begin{tabular}{|c|c|c|c|}
\hline Constituent & \multicolumn{2}{|c|}{ Concentration } & $\begin{array}{c}\text { Specific } \\
\text { gravity } \\
\text { increment }\end{array}$ \\
\hline 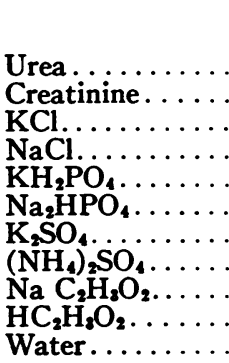 & $\begin{array}{c}\text { grams per liter } \\
27.923 \\
1.753 \\
3.989 \\
4.530 \\
4.627 \\
0.512 \\
2.030 \\
2.273 \\
3.805 \\
0.144\end{array}$ & $\begin{array}{c}\text { mEq. }(m M .) \\
\text { per liter } \\
465.0 \\
15.5 \\
53.5 \\
77.5 \\
34.0 \\
7.2 \\
23.3 \\
34.4 \\
46.4^{*} \\
2.4^{*}\end{array}$ & $\begin{array}{l}0.00753 \\
0.00044 \\
0.00254 \\
0.00320 \\
0.00328 \\
0.00049 \\
0.00163 \\
0.00133 \\
0.00194 \\
0.00002 \\
0.99823\end{array}$ \\
\hline \multicolumn{3}{|c|}{ Specific gravity (calculated)........... } & 1.02063 \\
\hline \multicolumn{3}{|c|}{ Specific gravity (observed)............ } & 1.0202 \\
\hline
\end{tabular}

* Acetate added as $48.8 \mathrm{cc}$. of $\mathrm{N}$ acetic acid + $46.4 \mathrm{cc}$. of $\mathrm{N}$ sodium hydroxide to obtain the ratio of salt to acid existing at $\mathrm{pH}$ 5.9.

lar calculations to more than one solute: First, each individual substance must contribute its effect without influencing or being influenced by other substances; and second, interchange of anions and cations must not affect the above factors.

A study of the latter assumption leads to an interesting observation pointed out by Valson (41). A mixture of $100 \mathrm{mEq}$. of $\mathrm{NaCl}$ and 100 $\mathrm{mEq}$. of $\mathrm{K}_{2} \mathrm{SO}_{4}$ in one liter of solution has a calculated specific gravity $\frac{20^{\circ}}{4^{\circ}}=0.99823\left(\mathrm{H}_{2} \mathrm{O}\right)$ $+0.00413(\mathrm{NaCl})+0.00700\left(\mathrm{~K}_{2} \mathrm{SO}_{4}\right)=1.00936$. Such a solution may equally well be considered as containing $100 \mathrm{mEq}$. each of $\mathrm{KCl}$ and $\mathrm{Na}_{2} \mathrm{SO}_{4}$. In this case, specific gravity $\frac{20^{\circ}}{4^{\circ}}=0.99823\left(\mathrm{H}_{2} \mathrm{O}\right)$ $+0.00475(\mathrm{KCl})+0.00642\left(\mathrm{Na}_{2} \mathrm{SO}_{4}\right)=1.00940$. The determined value is 1.0094 . In other words, the factor determined for each of the electrolytes in the above table is in reality a summation of two ionic factors each independent of the other. Further study of Table I reveals that this is apparently a general phenomenon. The five cations listed show differences in factors between $\mathrm{Cl}$ and $\mathrm{SO}_{4}$ of $0.00229,0.00225,0.00222,0.00214$, and 0.00218 ; i.e., for any given cation as sulphate, a $100 \mathrm{mEq}$. solution has a specific gravity at $\frac{20^{\circ}}{4^{\circ}}$ 
TABLE III

Calculated and observed specific gravity of urine after addition of salts and urea

\begin{tabular}{|c|c|c|c|c|c|}
\hline \multirow{2}{*}{$\begin{array}{l}\text { Subotance } \\
\text { added }\end{array}$} & \multirow{2}{*}{$\begin{array}{l}\text { Concen- } \\
\text { tration }\end{array}$} & \multirow{2}{*}{$\begin{array}{l}\text { Specifio } \\
\text { gravity } \\
\text { inerement } \\
\text { of } \\
\text { added } \\
\text { substances }\end{array}$} & \multicolumn{2}{|c|}{ Specific gravity } & \multirow{2}{*}{$\begin{array}{l}\text { Difference } \\
\text { (Caleu- } \\
\text { lated- } \\
\text { observed) }\end{array}$} \\
\hline & & & Calculated & Observed & \\
\hline & $\underset{\text { per liter }}{m E q}(m M)$. & & & & \\
\hline
\end{tabular}

(Original specifio gravity of urine $=1.0277$ )

\begin{tabular}{|c|c|c|c|c|c|}
\hline 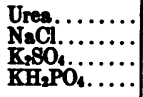 & $\begin{array}{l}417.4 \\
205.4 \\
103.9 \\
102.8\end{array}$ & $\begin{array}{l}0.00676 \\
0.00848 \\
0.00727 \\
0.00093\end{array}$ & $\begin{array}{l}1.0945 \\
1.0562 \\
1.0550 \\
1.0376\end{array}$ & $\begin{array}{l}1.0538 \\
1.0556 \\
1.0547 \\
1.0572\end{array}$ & $\begin{array}{l}0.0007 \\
0.0006 \\
0.0003 \\
0.0004\end{array}$ \\
\hline
\end{tabular}

(Original specifio gravity of urine $\mathbf{= 1 . 0 1 8 5}$ )

\begin{tabular}{|c|c|c|c|c|c|}
\hline $\begin{array}{l}\text { Urea.......... } \\
\mathrm{NaCh}_{2} \ldots \ldots \ldots \\
\mathrm{K}_{2} \mathrm{SO}_{4} \ldots \ldots \ldots \\
\mathrm{KH}_{2} \mathrm{PO}_{4} \ldots \ldots\end{array}$ & $\begin{array}{l}416.4 \\
205.5 \\
105.8 \\
103.2\end{array}$ & $\begin{array}{l}0.00674 \\
0.00848 \\
0.00727 \\
0.00996\end{array}$ & $\begin{array}{l}1.0252 \\
1.0270 \\
1.0258 \\
1.0285\end{array}$ & $\begin{array}{l}1.0246 \\
1.0265 \\
1.0264 \\
1.0279\end{array}$ & $\begin{array}{l}0.0006 \\
0.0005 \\
0.0004 \\
0.0006\end{array}$ \\
\hline
\end{tabular}

about 0.0022 higher than the same concentration of cation as chloride. The ionic nature of these specific gravity effects is not quite so exactly apparent throughout the table, particularly with some of the phosphates. This probably indicates partial ionization of the secondary and tertiary hydrogen. The cases where the agreement is poorest are those involving substances present in relatively small amounts in urine, so no attempt has been made to check these factors more closely.

In order to test the accuracy of specific gravity calculations of solutions approximating urine in composition, a number of " artificial urines" were studied. These were prepared by weighing the pure substances and dissolving them in water to a volume of one liter at $20^{\circ}$. Table II shows the composition and the calculated and observed specific gravities of one of these. This was a duplication of a normal urine, the composition of which had been determined by analysis, but the "artificial urine" contained only those substances for which specific gravity factors were available. Sodium acetate was used as representative of organic acids. The $\mathrm{pH}$ of this solution was 5.90 , of the original urine, 5.88 .

Five such " artificial urines" were studied with total solid contents ranging from 38.4 to 53.4 grams per liter. The maximum difference between calculated and observed specific gravity was 0.0007 , the average 0.0004 .

Another method of studying the applicability of the above specific gravity factors to solutions of mixed solutes is to dissolve a substance in urine of previously determined specific gravity. Data from an experiment of this type are given in Table III. A weighed amount of solid was dissolved in urine, made up to a volume of $100 \mathrm{cc}$., and the specific gravity was determined by pyknometer and compared with the calculated value.

The average difference of 0.0005 between calculated and observed specific gravity is an indication of the approximate error involved in the calculation, and compares with the value 0.0004 observed as the average in " artificial urines." It represents the summation of the specific volume effects of the solutes. The first part of Table III represents specific gravities about as high as will be encountered in normal human urine, while the values in the second part are in the upper range of normal.

From this it may be concluded that the maximum error in calculating the specific gravity of a solution similar in composition to urine is less than 0.0010 , and more likely of the order of 0.0005 .

If Weiser and Thelen's postulate (43) that a significant portion of the specific gravity of urine is the result of volume contraction or other physicochemical effects be correct, these should diminish as the urine becomes more dilute. A concentrated urine in which such effects would be pronounced should on increasing dilution approach a straightline relationship between total concentration and specific gravity increment in the range of low specific gravities although deviating significantly from linearity at higher specific gravities. This was not found to be the case. When a concentrated urine was diluted with water specific gravity increment was always a linear function of the degree of dilution, at least within two units in the fourth decimal place.

\section{Calculation of the specific gravity of normal urine}

Since the specific gravity of a complex solution with a total concentration of solutes of the order of magnitude found in urine can be calculated satisfactorily when the composition of the solution is known, an attempt can justifiably be made to calculate the specific gravity of urine from analysis of its major constituents.

Urine was collected from 6 normal males between the ages of 14 and 32 . All subjects were given a weighed diet for a week before collections began and remained on that diet throughout the collection period. Two diets were used: "high" protein containing 100 grams or 110 
grams, and "low" protein containing 40 grams or 50 grams daily. The remainder of the diet was adjusted to supply a total energy value of 2,300 to 3,000 calories. The daily ingestion of salt was kept approximately constant and the water intake varied to yield urines of specific gravity from 1.003 to 1.028 .

Urine was collected over 24-hour periods in chemically clean glass jars containing toluene and stored during the collection period in a refrigerator at $3^{\circ}-6^{\circ} \mathrm{C}$. The analyses were performed immediately following the close of the period.

Urine volume was measured in graduated cylinders of appropriate size, involving an error of less than 1 per cent. Specific gravities were determined with a Westphal balance at $20^{\circ} \mathrm{C}$., using a bob calibrated to give $D \frac{20^{\circ}}{4^{\circ}}$. By checking the balance from time to time, the maximum error in determination was kept below 0.0002. Protein as determined by the Shevky-Stafford method (37) was not present in sufficient quantity to affect the observed specific gravity.

Hydrogen ion concentrations were determined in the earlier experiments by the bicolor method of Hastings, Sendroy and Robson (37). Later, measurements were made with the Leeds and Northrup glass electrode assembly Number 7661-A1. When values in the upper $\mathrm{pH}$ range were anticipated, the urine specimens were collected with precaution against loss of $\mathrm{CO}_{2}$ and stored under oil.

The analytical methods employed were: total nitrogen by micro Kjeldahl; urea, Van Slyke and Cullen or Van Slyke; ammonia, aeration and titration; creatinine, Folin colorimetric; uric acid, Benedict and Franke; potassium, Kramer and Tisdall; sodium, Butler and Tuthill; chloride, Volhard-Harvey or Van Slyke and Sendroy; sulphur (inorganic, ethereal, and neutral), gravimetric methods of Folin and Benedict; inorganic phosphate, Pincus and Malot; organic acids, Van Slyke and Palmer; carbon dioxide content, Van Slyke (37) ; total base, Wright and Allison (45). The sum of calcium and magnesium was calculated by subtracting $\mathrm{Na}^{+}+\mathrm{K}^{+}$from total fixed base. The ratio of $\mathrm{HPO}_{4}$ to $\mathrm{H}_{2} \mathrm{PO}_{4}$ was calculated from the $\mathrm{pH}$. Bicarbonate was calculated from the total $\mathrm{CO}_{2}$ by the Henderson-Hasselbalch equation, using the determined $\mathrm{pH}$ and the $\mathrm{pK}^{1}$ calculated from total base content according to Sendroy, Seelig and Van Slyke (40a).

Total urine solids were determined by an application of the "cryochem" process of Flosdorf and Mudd (15). Ten cc. specimens of urine in glass evaporating dishes were frozen in an alcohol-solid $\mathrm{CO}_{2}$ mixture and dehydrated for 24 hours in the frozen state in a vacuum desiccator over freshly dried granular calcium sulphate, using a Cenco "Hyvac" pump. With control solutions, 24-hour drying was found to be sufficient to remove the water completely. Duplicate urine samples always checked at the end of this period but, with continued exposure to the high vacuum, the urine residues showed a progressive slow loss of weight amounting to about 1 per cent every 24 hours up to 96 hours.

This method of drying, while largely obviating errors due to decomposition of the constituents of urine at higher temperatures, results in the loss of volatile substances such as carbon dioxide from bicarbonate and volatile fatty acids. The continued removal of such substances is probably largely responsible for the decrease in weight after the first 24 hours.

The acid-base balance of the electrolytes and the nitrogen partition were calculated as checks on the accuracy of the determinations.

From the urine analyses and the specific gravity factors (Table I), the increments of specific gravity contributed by each of the analyzed substances can be calculated and the sum compared with the observed total increment.

Three methods are available in handling the salts :

(A) The various anions and cations may be combined in any convenient way to form salts, and the salt concentrations used in the calculation. As previously shown, the method of combination is immaterial.

(B) The $\mathrm{Na}^{+}, \mathrm{K}^{+}$, and $\mathrm{NH}_{4}{ }^{+}$ions may be partitioned among each of the anions according to their percentages of the total cation. For this purpose $\mathrm{Ca}^{++}+\mathrm{Mg}^{++}$are grouped with $\mathrm{Na}^{+}$. This grouping of $\mathrm{Ca}^{++}+\mathrm{Mg}^{++}$with $\mathrm{Na}^{+}$is justified, as can be seen from the specific gravity factors of Table I. $\mathrm{Ca}^{++}$has a slightly greater and $\mathrm{Mg}^{++}$a slightly smaller effect on specific gravity than $\mathrm{Na}$ and since they are present in roughly the same concentration, both being small, the error in grouping them with $\mathrm{Na}$ is slight. ${ }^{2}$

$(C)$ The anions may be considered as present entirely in the form of $\mathrm{Na}$ salts.

Methods $A$ and $B$ are both somewhat tedious but yield the same result. Method $C$, which at first glance seems to be only a rough approximation, also gives the same value as $A$ or $B$. This is due to a fortuitous balancing of the $\mathrm{K}$ and $\mathrm{NH}_{4}$ concentrations and factors, and presumably would not always hold. If $\mathrm{K}$ or $\mathrm{NH}_{4}$ concentrations de-

2 In a urine containing $30 \mathrm{mEq}$. per liter of $\mathrm{Ca}+\mathrm{Mg}$ (the maximum in our series), the error in calculating specific gravity by considering this fraction of cation as $\mathrm{Na}$ would be -.00012 if it were all $\mathrm{Ca}$ and +0.00008 if it were all $\mathrm{Mg}$. If present in the usual proportions, the errors are almost completely balanced. This would not be true in urines where the cation distribution varies greatly from the normal (low salt intake, nephrosis, etc.). In such cases, $\mathrm{Ca}$ and $\mathrm{Mg}$ should be determined as well as $\mathrm{Na}$ and $\mathrm{K}$. 
viate much from the normal, Method $A$ or $B$ is to be preferred.

Table IV illustrates the calculation of the specific gravity of a mixed salt solution made up in approximately the same concentration as one of the normal urines. It will be seen that the three methods of calculation agree quite closely and are well within the limits of analytical errors.

The specific gravity of twenty normal urines from subjects on the standard diets was calculated by both Methods $B$ and $C$, using the experimentally determined concentrations of $\mathrm{Na}, \mathrm{K}$, and $\mathrm{NH}_{4}$ for $B$. Method $B$ tends to give slightly lower values, but in no case does the difference exceed0.0004 . Fourteen of the twenty are identical or differ by 0.0001 ; seventeen do not differ by more than 0.0002 .

Where $\mathrm{Na}$ and $\mathrm{K}$ were determined, Method $B$ was used throughout. In some of the earlier experiments where these were not determined, Method $C$ was used.

The experimental data from the first series of experiments on 2 male subjects with normal renal function (ages 32 and 28) are given in Table V. The subjects were ambulatory during the experimental periods but exercise was limited in order to minimize salt and $\mathrm{N}$ loss by perspiration.

Since the acid-base balance involved eight analyses, a maximum difference between acidic and basic radicals of 10 per cent was arbitrarily chosen for the selection of urines for calculation of specific gravity. In most instances, the error was less than 5 per cent. On high protein diets, the sum of the cations is usually less than the sum of the anions, probably because the organic acids have been considered to be present entirely as salts (i.e., as anions). On high protein diets, $\mathrm{pH}$ is consistently lower due to increased excretion of the acid products of protein catabolism. In these more acid urines, some of the organic acids may exist uncombined, amounting possibly to as much as 10 per cent at $\mathrm{pH} 5.0$ (assuming an average $\mathrm{pK}$ of 4.0 ) and this nonionized fraction should not be used in calculating the acid-base balance. Since this correction cannot be accurately estimated, the organic acids have been grouped entirely with the anions,

TABLE IV

Comparison of methods for the calculation of specific gravity

\begin{tabular}{|c|c|c|c|c|c|c|c|c|}
\hline \multicolumn{3}{|c|}{ Method A } & \multicolumn{3}{|c|}{ Method B } & \multicolumn{3}{|c|}{ Method C } \\
\hline Constituent & $\begin{array}{l}\text { Concen- } \\
\text { tration }\end{array}$ & $\begin{array}{c}\text { Specific } \\
\text { gravity } \\
\text { increment }\end{array}$ & Constituent & $\begin{array}{l}\text { Concen- } \\
\text { tration }\end{array}$ & $\begin{array}{c}\text { Specific } \\
\text { gravity } \\
\text { increment }\end{array}$ & Constituent & $\begin{array}{c}\text { Concen- } \\
\text { tration }\end{array}$ & $\begin{array}{c}\text { Specific } \\
\text { gravity } \\
\text { increment }\end{array}$ \\
\hline $\begin{array}{l}\mathrm{KCl} \\
\mathrm{NaCl}\end{array}$ & \begin{tabular}{|c|}
$m E q$. per liter \\
53.5 \\
77.5
\end{tabular} & $\begin{array}{l}0.00254 \\
0.00320\end{array}$ & $\begin{array}{l}\mathrm{KCl} \\
\mathrm{NH}_{4} \mathrm{Cl} \\
\mathrm{NaCl}\end{array}$ & \begin{tabular}{|c|}
$m E q$. per liter \\
63.2 \\
19.6 \\
48.2
\end{tabular} & $\begin{array}{l}0.00300 \\
0.00033 \\
0.00199\end{array}$ & $\mathrm{NaCl}$ & $\begin{array}{c}m E q . \text { per liter } \\
131.0\end{array}$ & 0.00541 \\
\hline $\begin{array}{l}\mathrm{K}_{2} \mathrm{SO}_{4} \\
\left(\mathrm{NH}_{4}\right)_{2} \mathrm{SO}_{4}\end{array}$ & $\begin{array}{l}23.3 \\
34.4\end{array}$ & $\begin{array}{l}0.00163 \\
0.00133\end{array}$ & $\begin{array}{l}\mathrm{K}_{2} \mathrm{SO}_{4} \\
\left(\mathrm{NH}_{4}\right)_{2} \mathrm{SO}_{4} \\
\mathrm{Na}_{2} \mathrm{SO}_{4}\end{array}$ & $\begin{array}{r}27.8 \\
8.7 \\
21.2\end{array}$ & $\begin{array}{l}0.00195 \\
0.00034 \\
0.00136\end{array}$ & $\mathrm{Na}_{2} \mathrm{SO}_{4}$ & 57.7 & 0.00370 \\
\hline $\mathrm{KH}_{2} \mathrm{PO}_{4}$ & 34.0 & 0.00328 & $\begin{array}{l}\mathrm{KH}_{2} \mathrm{PO}_{4} \\
\mathrm{NH}_{4} \mathrm{H}_{2} \mathrm{PO}_{4} \\
\mathrm{NaH}_{2} \mathrm{PO}_{4}\end{array}$ & $\begin{array}{r}16.4 \\
5.1 \\
12.5\end{array}$ & $\begin{array}{l}0.00158 \\
0.00038 \\
0.00112\end{array}$ & $\mathrm{NaH}_{2} \mathrm{PO}_{4}$ & 34.0 & 0.00304 \\
\hline $\mathrm{Na}_{2} \mathrm{HPO}$ & 7.2 & 0.00049 & $\begin{array}{l}\mathrm{K}_{2} \mathrm{HPO}_{4} \\
\left(\mathrm{NH}_{4}\right)_{2} \mathrm{HPO}_{4} \\
\mathrm{Na}_{2} \mathrm{HPO}_{4}\end{array}$ & $\begin{array}{l}3.5 \\
1.1 \\
2.6\end{array}$ & $\begin{array}{l}0.00025 \\
0.00004 \\
0.00018\end{array}$ & $\mathrm{Na}_{2} \mathrm{HPO}_{4}$ & 7.2 & 0.00049 \\
\hline $\mathrm{H}_{2} \mathrm{O}$ & & 0.99823 & $\mathrm{H}_{2} \mathrm{O}$ & & 0.99823 & $\mathrm{H}_{2} \mathrm{O}$ & & 0.99823 \\
\hline \multicolumn{2}{|l|}{ Specific gravity } & 1.01070 & \multicolumn{2}{|l|}{ Specific gravity } & 1.01075 & \multicolumn{2}{|l|}{ Specific gravity } & 1.01087 \\
\hline
\end{tabular}

Observed specific gravity $=1.0108$

Method A: Calculated according to composition as actually prepared.

Method $\mathrm{B}$ : Cations distributed proportionally among anions. $\left(\mathrm{Na}=36.8\right.$ per cent, $\mathrm{K}=48.2$ per cent, $\mathrm{NH}_{4}=15.0$ per cent of total cation.)

Method C: Anions considered as being present entirely as sodium salts. 
TABLE $\mathbf{v}$

Concentrations of major constituents and acid-base balance of twenty-two urines from 2 subjects on low and high protein diets

\begin{tabular}{|c|c|c|c|c|c|c|c|c|c|c|c|c|c|c|c|c|c|}
\hline$\underset{\text { ject }}{\text { Sub- }}$ & $\begin{array}{l}\text { Vol- } \\
\text { ume }\end{array}$ & $\begin{array}{l}\text { Specific } \\
\text { gravity }\end{array}$ & $\mathrm{pH}$ & Urea & $\begin{array}{c}\text { Cre- } \\
\text { atinine }\end{array}$ & $\begin{array}{l}\text { Total } \\
\text { base }\end{array}$ & $\mathrm{NH}_{4}$ & $\mathrm{Cl}$ & So, & $\mathrm{H}_{2} \mathrm{PO}_{4}$ & HPO. & $\mathrm{HCO}_{3}$ & $\begin{array}{c}\text { Organic } \\
\text { acid }\end{array}$ & $\underset{\text { Base }}{2}$ & $\underset{\text { Acid }}{\Sigma}$ & $\begin{array}{l}\text { Base- } \\
\text { acid }\end{array}$ & Error \\
\hline & $c c$. & & & $\underset{\substack{\text { per } \\
\text { liter }}}{\operatorname{mM}}$ & $\underset{\substack{\text { per } \\
\text { liter }}}{m M}$ & $\begin{array}{c}\text { mEq. } \\
\text { per } \\
\text { liter }\end{array}$ & $\begin{array}{c}m E q . \\
\text { per } \\
\text { liter }\end{array}$ & $\begin{array}{c}m E q . \\
\text { per } \\
\text { liter }\end{array}$ & $\begin{array}{c}\text { mEq. } \\
\text { per } \\
\text { liter }\end{array}$ & $\begin{array}{c}\text { mEq. } \\
\text { per } \\
\text { liter }\end{array}$ & $\begin{array}{c}\text { mEq. } \\
\text { liter }\end{array}$ & $\begin{array}{c}\text { per. } \\
\text { liter }\end{array}$ & $\begin{array}{c}\text { per } \\
\text { liter }\end{array}$ & $\begin{array}{c}m E q . \\
p \in r \\
\text { liter }\end{array}$ & $\begin{array}{c}m E q . \\
\text { per } \\
\text { liter }\end{array}$ & $\begin{array}{c}m E q . \\
p q r \\
\text { liter }\end{array}$ & $\begin{array}{l}\text { per } \\
\text { cent }\end{array}$ \\
\hline
\end{tabular}

D (40 Gram protein diet) Age 30 . Ht. $173.5 \mathrm{~cm}$. Wt. $56.6 \mathrm{kgm}$.

\begin{tabular}{l|r|r|r|r|r|r|r|r|r|r|r|r|r|r|r|r|r|r}
\hline a & 1500 & 1.0080 & 6.2 & 98.3 & 7.4 & 110.1 & 10.5 & 61.6 & 13.8 & 11.6 & 5.3 & 1.4 & 23.9 & 120.6 & 117.6 & 3.0 & 2.5 \\
b & 415 & 1.0283 & 6.3 & 296.0 & 23.7 & 349.5 & 26.6 & 167.9 & 54.1 & 40.2 & 23.2 & 2.0 & 107.2 & 376.1 & 394.6 & -18.5 & -4.8 \\
c & 460 & 1.0275 & 6.7 & 322.0 & 21.3 & 328.3 & 24.4 & 152.5 & 45.0 & 29.3 & 45.2 & 5.0 & 74.1 & 352.7 & 351.1 & 1.6 & 0.5 \\
d & 725 & 1.0162 & 6.4 & 199.8 & 15.4 & 216.4 & 21.5 & 111.5 & 28.1 & 20.4 & 14.9 & 0.9 & 40.8 & 237.9 & 216.6 & 21.3 & 9.4 \\
e & 3240 & 1.0030 & 6.6 & 51.9 & 3.2 & 58.7 & 5.5 & 32.5 & 6.1 & 4.5 & 5.4 & 3.1 & 9.2 & 64.2 & 60.8 & 3.4 & 5.5 \\
f & 2790 & 1.0037 & 6.5 & 52.2 & 3.8 & 68.0 & 6.1 & 36.6 & 7.6 & 6.8 & 6.3 & 2.8 & 10.2 & 74.1 & 70.3 & 3.8 & 5.3 \\
\hline
\end{tabular}

D (100 Gram protein diet)

\begin{tabular}{l|r|r|r|r|r|r|r|r|r|r|r|r|r|r|r|r|r|r}
\hline a & 1000 & 1.0238 & 5.2 & 396.0 & 14.1 & 274.7 & 29.1 & 171.3 & 54.3 & 34.8 & 1.8 & 0.1 & 40.3 & 303.8 & 302.6 & 1.2 & 0.4 \\
b & 1020 & 1.0248 & 5.2 & 443.0 & 12.4 & 290.5 & 28.6 & 208.3 & 53.2 & 36.0 & 2.0 & 0.1 & 40.8 & 319.1 & 304.4 & 14.7 & 4.7 \\
c & 985 & 1.0275 & 5.1 & 472.0 & 11.7 & 284.5 & 30.6 & 189.8 & 60.0 & 38.6 & 1.8 & 0.1 & 32.8 & 315.1 & 323.1 & -8.0 & -2.5 \\
d & 1000 & 1.0266 & 5.2 & 503.0 & 13.4 & 314.9 & 29.6 & 215.3 & 59.8 & 33.7 & 1.8 & 0.1 & 40.0 & 344.5 & 350.7 & -6.2 & -1.8 \\
e & 3020 & 1.0064 & 5.0 & 160.0 & 4.2 & 80.4 & 16.0 & 63.3 & 18.7 & 10.5 & 0.4 & - & 11.1 & 96.4 & 104.0 & -7.6 & -7.6 \\
f & 3480 & 1.0063 & 5.2 & 146.0 & 3.5 & 92.1 & 11.0 & 66.0 & 17.5 & 9.7 & 0.3 & - & 11.1 & 103.1 & 104.9 & -1.8 & -1.7 \\
g & 1640 & 1.0136 & 5.2 & 311.0 & 8.6 & 153.8 & 20.1 & 90.0 & 34.7 & 22.5 & 1.2 & 0.1 & 21.8 & 173.9 & 170.3 & 3.6 & 2.1 \\
h & 1790 & 1.0127 & 5.2 & 283.0 & 7.8 & 154.6 & 19.6 & 104.7 & 33.3 & 20.2 & 1.0 & 0.1 & 26.5 & 174.2 & 185.8 & -11.6 & -6.4 \\
\hline
\end{tabular}

M (50 Gram protein diet) Age $28 . \quad H t .180 \mathrm{~cm}$. Wt. $72.5 \mathrm{kgm}$.

\begin{tabular}{l|r|r|r|r|r|r|r|r|r|r|r|r|r|r|r|r|r|r|r|r|r|r|}
\hline a & 890 & 1.0217 & 6.6 & 300.6 & 18.6 & 255.8 & 35.1 & 148.8 & 39.1 & 20.6 & 24.8 & 3.5 & 43.1 & 290.9 & 279.9 & 11.0 & 3.9 \\
b & 580 & 1.0265 & 6.4 & 355.0 & 23.1 & 300.9 & 28.8 & 188.4 & 45.1 & 26.3 & 19.2 & 4.0 & 48.7 & 329.7 & 331.7 & -2.0 & -0.6 \\
c & 1980 & 1.0080 & 6.7 & 128.5 & 7.7 & 124.5 & 10.7 & 75.9 & 14.5 & 7.1 & 10.8 & 7.6 & 17.8 & 135.2 & 133.7 & 1.5 & 1.1 \\
d & 1410 & 1.0110 & 6.6 & 161.6 & 10.2 & 149.3 & 15.1 & 92.3 & 20.0 & 10.1 & 12.2 & 4.5 & 23.0 & 164.4 & 162.1 & 2.3 & 1.4 \\
\hline
\end{tabular}

M (110 Gram protein diet)

\begin{tabular}{l|r|r|r|r|r|r|r|r|r|r|r|r|r|r|r|r|r}
\hline a & 1635 & 1.0171 & 5.7 & 311.7 & 9.3 & 195.7 & 26.4 & 140.2 & 38.3 & 23.4 & 3.2 & 0.9 & 23.9 & 222.1 & 229.9 & -7.8 & -3.5 \\
b & 1160 & 1.0229 & 5.7 & 396.0 & 14.8 & 265.1 & 32.8 & 205.9 & 50.4 & 27.7 & 3.8 & 0.6 & 33.1 & 297.9 & 321.5 & -23.6 & -7.6 \\
c & 2350 & 1.0105 & 6.2 & 225.0 & 6.8 & 136.0 & 14.1 & 86.3 & 26.0 & 12.7 & 5.8 & 2.0 & 16.8 & 150.1 & 149.6 & 0.5 & 0.3 \\
d & 2920 & 1.0080 & 5.7 & 182.5 & 5.6 & 91.1 & 13.6 & 55.1 & 21.8 & 13.2 & 1.8 & 0.5 & 14.4 & 104.7 & 106.8 & -2.1 & -2.0 \\
\hline
\end{tabular}

giving, in the more acid urines, a total concentration of acidic constituents bound to base slightly in excess of the amount actually present.

Using the factors given in Table I, the specific gravity contributions of urea, creatinine, chloride, sulfate, phosphate, and bicarbonate were calculated by Method $C$. Data of the 2 subjects, D. and M., are presented in Table VI. In addition to these 2 subjects, similar studies were carried out on 5 more individuals (subject $M$ was studied again 6 months after the first experiments). The average per cent of specific gravity determined on the two protein diets is given in Table VII. (Method $B$ was used in calculations in the last four subjects.)

In a person with normal kidney function on a relatively constant diet, the specific gravity con- tributions of the substances enumerated above are fairly constant, since they are for the most part derived from exogenous soųrces and during a 24hour period will be almost completely excreted, provided the subject is in balance. Urine volume changes over normal ranges will not affect output appreciably; consequently these substances will be diluted or concentrated to the same degree and the specific gravity effect expressed on a percentage basis will remain constant. Over a range of specific gravity from 1.0030 to 1.0283 , on either low or high protein diet, the same specific gravity pattern is obtained.

On a high protein diet, relatively more of the specific gravity can be accounted for, the total averaging between 80 and 90 per cent, as compared 
TABLE VI

Calculations of specific gravity (method $C$ ) from data of Table $V$, using factors of Table I

\begin{tabular}{|c|c|c|c|c|c|c|c|c|c|c|c|c|c|c|c|c|c|}
\hline \multirow{2}{*}{ Sub- } & \multirow{2}{*}{$\begin{array}{c}\text { Spe- } \\
\text { cific } \\
\text { gravity } \\
\text { incre- } \\
\text { ment }\end{array}$} & \multicolumn{14}{|c|}{ Contributions to specific gravity of } & \multirow{2}{*}{$\begin{array}{l}\text { Sum of } \\
\text { specific } \\
\text { gravity } \\
\text { contri- } \\
\text { butions }\end{array}$} & \multirow{2}{*}{$\begin{array}{l}\text { Per cent } \\
\text { specific } \\
\text { gravity } \\
\text { deter- } \\
\text { mined }\end{array}$} \\
\hline & & Urea & $\begin{array}{l}\text { Per } \\
\text { cent }\end{array}$ & $\begin{array}{c}\text { Creati- } \\
\text { nine }\end{array}$ & $\begin{array}{l}\text { Per } \\
\text { cent }\end{array}$ & $\mathrm{NaCl}$ & $\begin{array}{l}\text { Per } \\
\text { cent }\end{array}$ & $\mathrm{Na}_{2} \mathrm{SO}_{4}$ & $\begin{array}{l}\text { Per } \\
\text { cent }\end{array}$ & $\mathrm{NaH}_{2} \mathrm{PO}$ & $\begin{array}{l}\text { Per } \\
\text { cent }\end{array}$ & $\mathrm{Na}_{2} \mathrm{HPO}_{4}$ & $\begin{array}{l}\text { Per } \\
\text { cent }\end{array}$ & $\mathrm{NaHCO}_{2}$ & $\begin{array}{l}\text { Per } \\
\text { cent }\end{array}$ & & \\
\hline $\begin{array}{r}\mathbf{D} \text { (a) } \\
\text { (b) } \\
\text { (c) } \\
\text { (d) } \\
\text { (e) } \\
\text { (f) }\end{array}$ & $\begin{array}{l}0.0098 \\
0.0301 \\
0.0293 \\
0.0180 \\
0.0048 \\
0.0055\end{array}$ & \begin{tabular}{|r|}
0.00159 \\
480 \\
522 \\
324 \\
84 \\
85
\end{tabular} & \begin{tabular}{l|}
16.2 \\
16.0 \\
17.8 \\
18.0 \\
17.5 \\
15.5
\end{tabular} & \begin{tabular}{|r|}
0.00021 \\
68 \\
61 \\
44 \\
09 \\
11
\end{tabular} & $\begin{array}{l}2.1 \\
2.3 \\
2.1 \\
2.4 \\
1.9 \\
2.0\end{array}$ & \begin{tabular}{|r}
0.00254 \\
694 \\
630 \\
461 \\
135 \\
151
\end{tabular} & $\begin{array}{l}25.9 \\
23.1 \\
21.5 \\
25.6 \\
28.1 \\
27.5\end{array}$ & \begin{tabular}{|r|}
.00089 \\
347 \\
289 \\
180 \\
39 \\
49
\end{tabular} & $\begin{array}{r}9.1 \\
11.5 \\
9.9 \\
10.0 \\
8.1 \\
8.9\end{array}$ & \begin{tabular}{|r}
0.00104 \\
359 \\
262 \\
182 \\
40 \\
61
\end{tabular} & $\begin{array}{r}10.6 \\
11.9 \\
8.9 \\
10.1 \\
8.3 \\
11.1\end{array}$ & \begin{tabular}{|r|}
0.00036 \\
157 \\
305 \\
100 \\
36 \\
43
\end{tabular} & \begin{tabular}{r|}
3.7 \\
5.2 \\
10.4 \\
5.6 \\
7.5 \\
7.8
\end{tabular} & \begin{tabular}{|r|}
0.00009 \\
12 \\
30 \\
5 \\
19 \\
17
\end{tabular} & $\begin{array}{l}0.9 \\
0.4 \\
1.2 \\
0.3 \\
4.0 \\
3.1\end{array}$ & \begin{tabular}{|l}
0.00672 \\
0.02117 \\
0.02099 \\
0.01296 \\
0.00362 \\
0.00417
\end{tabular} & $\begin{array}{l}68.6 \\
70.2 \\
71.6 \\
72.0 \\
75.2 \\
75.8\end{array}$ \\
\hline
\end{tabular}

\begin{tabular}{|c|c|c|c|c|c|c|c|c|c|c|c|c|c|c|c|c|}
\hline $\begin{array}{c}\text { D (a) } \\
\text { (b) } \\
\text { (c) } \\
\text { (d) } \\
\text { (e) } \\
\text { (f) } \\
\text { (g) } \\
\text { (h) }\end{array}$ & $\begin{array}{l}0.0256 \\
0.0266 \\
0.0293 \\
0.0284 \\
0.0082 \\
0.0081 \\
0.0154 \\
0.0145\end{array}$ & $\begin{array}{r}0.00642 \\
718 \\
764 \\
815 \\
259 \\
237 \\
504 \\
459\end{array}$ & \begin{tabular}{|l|}
25.1 \\
27.0 \\
26.1 \\
28.7 \\
31.6 \\
29.3 \\
32.7 \\
31.7
\end{tabular} & \begin{tabular}{|r|}
0.00040 \\
35 \\
33 \\
38 \\
12 \\
10 \\
25 \\
22
\end{tabular} & $\begin{array}{l}1.6 \\
1.3 \\
1.1 \\
1.3 \\
1.5 \\
1.2 \\
1.6 \\
1.5\end{array}$ & $\begin{array}{r}0.00708 \\
861 \\
784 \\
890 \\
261 \\
273 \\
372 \\
433\end{array}$ & $\begin{array}{l}27.7 \\
32.4 \\
26.8 \\
31.3 \\
31.8 \\
33.7 \\
24.2 \\
29.9\end{array}$ & $\begin{array}{r}0.00349 \\
342 \\
385 \\
384 \\
120 \\
112 \\
223 \\
214\end{array}$ & \begin{tabular}{|l|}
13.6 \\
12.9 \\
13.1 \\
13.5 \\
14.6 \\
13.8 \\
14.5 \\
14.8
\end{tabular} & $\begin{array}{r}0.00311 \\
322 \\
345 \\
301 \\
94 \\
87 \\
201 \\
181\end{array}$ & $\begin{array}{l}12.1 \\
12.1 \\
11.8 \\
10.6 \\
11.5 \\
10.7 \\
13.1 \\
12.5\end{array}$ & \begin{tabular}{|r}
0.00012 \\
13 \\
12 \\
12 \\
3 \\
2 \\
8 \\
7
\end{tabular} & $\begin{array}{l}0.5 \\
0.5 \\
0.4 \\
0.4 \\
0.4 \\
0.2 \\
0.5 \\
0.5\end{array}$ & $\begin{array}{r}0.00001 \\
1 \\
1 \\
1 \\
0 \\
0 \\
1 \\
1\end{array}$ & $\begin{array}{l}0.02063 \\
0.02292 \\
0.02324 \\
0.02441 \\
0.00749 \\
0.00721 \\
0.01334 \\
0.01317\end{array}$ & $\begin{array}{l}80.6 \\
86.2 \\
79.4 \\
86.0 \\
91.4 \\
89.0 \\
86.6 \\
90.8\end{array}$ \\
\hline
\end{tabular}

\begin{tabular}{r|r|r|r|r|r|r|r|r|r|r|r|r|r|r|r|r|r|r}
\hline$M$ (a) & 0.0235 & 0.00487 & 20.7 & 0.00053 & 2.3 & 0.00614 & 26.3 & 0.00251 & 10.7 & 0.00184 & 7.8 & 0.00167 & 7.1 & 0.00021 & 0.9 & 0.01777 & 75.6 \\
(b) & 0.0283 & 575 & 20.3 & 66 & 2.3 & 778 & 27.5 & 290 & 10.2 & 235 & 88.3 & 130 & 4.6 & 24 & 0.8 & 0.02098 & 74.1 \\
(c) & 0.0098 & 208 & 21.2 & 22 & 2.2 & 314 & 32.0 & 93 & 9.5 & 63 & 6.4 & 73 & 7.5 & 46 & 4.7 & 0.00819 & 83.6 \\
(d) & 0.0128 & 262 & 20.5 & 29 & 2.3 & 381 & 29.8 & 228 & 10.0 & 90 & 7.0 & 82 & 6.4 & 27 & 2.1 & 0.00999 & 78.0 \\
\hline
\end{tabular}

\begin{tabular}{r|l|l|l|l|l|l|l|l|l|l|l|l|l|l|l|l|l|l}
\hline$M$ (a) & $\mathbf{0 . 0 1 8 9}$ & 505 & 26.7 & 26 & 1.4 & 579 & 30.6 & 246 & 13.0 & 209 & 11.1 & 22 & 1.2 & 05 & 0.3 & 0.01592 & 84.2 \\
(b) & 0.0247 & 642 & 26.0 & 42 & 1.7 & 850 & 34.4 & 324 & 13.1 & 248 & 10.0 & 26 & 1.1 & 04 & 0.2 & 0.02136 & 86.5 \\
(c) & 0.0123 & 364 & 29.6 & 19 & 1.5 & 357 & 29.0 & 167 & 13.6 & 114 & 9.3 & 39 & 3.2 & 12 & 1.0 & 0.01072 & 87.2 \\
(d) & 0.0098 & 296 & 30.2 & 16 & 1.6 & 228 & 23.3 & 140 & 14.3 & 118 & 12.0 & 12 & 1.2 & 03 & 0.3 & 0.00813 & 83.0 \\
\hline
\end{tabular}

with 70 to 80 per cent on a low protein diet (Table VII). An increase in protein intake results in a greater output of urea, sulfate and phosphate without a proportional increase in water; that is, the normal human kidney seems to have the ability to eliminate successive increments of these substances with some economy of water ( $c f$. Gamble (19)). Their specific gravity contributions necessarily become proportionately greater, except in the case of phosphate where the increased molar concentration may be offset by the decrease in equivalent concentration resulting from the shift from alkaline to acid salts at the lower $\mathrm{pH}$ values.

The chloride fraction of specific gravity represents $1 / 5$ to $1 / 3$ of the total. In general, the chloride contribution to specific gravity was slightly less with the high protein diet since the salt intake was only slightly increased.

Creatinine contributed only a small quantity (1 to 2 per cent), which was definitely less on the higher protein diet. Since creatinine is essentially a product of endogenous metabolism and since more solids are excreted on a high protein diet, creatinine makes up a smaller percentage of the total.
Bicarbonate was variable but usually did not comprise a very significant part of the total. The excretion of bicarbonate is dependent on $\mathrm{pH}$ and $\mathrm{CO}_{2}$ tension and at the acidity of normal urine and under a normal tension will not generally exceed $10 \mathrm{mEq}$. per liter $(18,40 \mathrm{~b})$.

These data indicate that 70 to 90 per cent of the specific gravity of the urine from normal subjects on varying protein diets can be accounted for by chloride, urea, sulfate, phosphate, creatinine, and bicarbonate. Of these, chloride contributes roughly 25 per cent, sulfate and phosphate together 20 to 30 per cent, urea 15 to 30 per cent, creatinine 1 to 2 per cent, and bicarbonate 0 to 5 per cent. Urea, sulfate, and phosphate, comprising the major derivatives of protein metabolism, make up a greater fraction on high protein diets.

\section{The undetermined fraction of specific gravity}

The remaining 10 to 30 per cent of the specific gravity unaccounted for on the basis of analyses is a fraction of much interest. In specific gravity units, it amounts to 0.0007 to 0.0061 on the high protein diet, and 0.0012 to 0.0089 on the low pro- 
tein diet, the absolute magnitude depending on the total gravity. Since it has been shown that in a solution such as urine interionic or other physicochemical factors do not significantly affect specific gravity, this relatively large undetermined fraction must be due to constituents of urine not determined by analysis.

For a more detailed study of this undetermined fraction, another series of nine normal urines from 4 subjects was analyzed. The conditions of diet, collection of samples, analytical methods, etc., were the same as for the previously studied series. In addition, $\mathrm{Na}, \mathrm{K}$, total solid, total carbon, and ash were determined. The analytical data were treated by Method $B$ (Table IV) for the calculation of specific gravity. The concentration of each substance analyzed was also expressed in grams from which the 24-hour output of determined substances could be calculated and the sum of these compared with the total solid output. The determined 24-hour output was further divided into organic (urea + creatinine) and inorganic fractions and these were compared with the

TABLE VII

Average determined percentage of specific gravity of urine from subjects on varying protein diets

\begin{tabular}{|c|c|c|c|c|c|c|c|c|c|}
\hline \multirow{2}{*}{ Sub- } & \multirow{2}{*}{$\begin{array}{l}\text { Num- } \\
\text { ber } \\
\text { of ob- } \\
\text { serva- } \\
\text { tions }\end{array}$} & \multirow{2}{*}{$\begin{array}{l}\text { Nitro- } \\
\text { gen } \\
\text { output }\end{array}$} & \multicolumn{6}{|c|}{$\begin{array}{l}\text { Per cent of specific gravity } \\
\text { accounted for by }\end{array}$} & \multirow{2}{*}{ Total } \\
\hline & & & Urea & Cl & SO, & $\mathrm{PO}_{1}$ & $\mathrm{HCO}_{2}$ & $\begin{array}{l}\text { Cre- } \\
\text { ati- } \\
\text { nine }\end{array}$ & \\
\hline & & grams & & & & & & & $\begin{array}{l}\text { per } \\
\text { cent }\end{array}$ \\
\hline
\end{tabular}

40-50 Grams protein diet

\begin{tabular}{l|l|l|l|l|r|r|r|r|r}
\hline Lom. & 6 & $4.6^{*}$ & 12.0 & 42.4 & 6.2 & 10.5 & 3.9 & 1.6 & 76.6 \\
D & 6 & $5.4^{*}$ & 16.8 & 25.3 & 9.6 & 16.9 & 1.7 & 2.1 & 72.4 \\
M & 4 & 8.4 & 20.7 & 28.9 & 10.1 & 13.8 & 1.6 & 2.3 & 77.4 \\
M† & 1 & 9.4 & 23.4 & 30.1 & 10.0 & 10.3 & 1.3 & 2.0 & 77.1 \\
L & 2 & 8.7 & 20.4 & 27.2 & 10.3 & 9.9 & 5.4 & 1.9 & 75.1 \\
B & 2 & 9.7 & 21.4 & 27.8 & 9.8 & 11.4 & 4.7 & 2.0 & 77.1 \\
K & 2 & $11.1^{*}$ & 24.4 & 22.8 & 11.9 & 13.0 & 1.0 & 2.2 & 75.3 \\
\hline
\end{tabular}

100-110 Grams protein diet

\begin{tabular}{l|l|l|l|l|l|l|l|l|l}
\hline Lom. & 7 & $10.5 *$ & 19.6 & 36.6 & 9.9 & 11.5 & 1.9 & 1.2 & 80.7 \\
D & 8 & 15.4 & 29.0 & 29.7 & 13.9 & 12.2 & 0.0 & 1.4 & 86.2 \\
M & 4 & 16.6 & 28.1 & 29.3 & 13.5 & 12.3 & 0.5 & 1.6 & 85.3 \\
M† & 1 & 16.7 & 28.3 & 27.5 & 14.2 & 13.9 & 0.2 & 1.6 & 85.7 \\
L & 1 & 16.4 & 30.2 & 22.5 & 14.7 & 14.9 & 0.5 & 1.5 & 84.3 \\
B & 2 & 17.3 & 29.7 & 22.6 & 13.4 & 13.8 & 0.5 & 1.6 & 81.6 \\
K & 2 & 17.5 & 30.3 & 19.2 & 14.2 & 14.4 & 0.2 & 1.7 & 80.0 \\
\hline
\end{tabular}

* Not in nitrogen balance.

† Six months after first set of observations.
TABLE VIII

Method of calculating specific gravity and output of solids of urine

Subject: B (May 25, 1939) $\quad 24$-Hour Vol. $=1260 \propto 2 . \quad D \frac{20^{\circ}}{4^{\circ}}=1.0145$

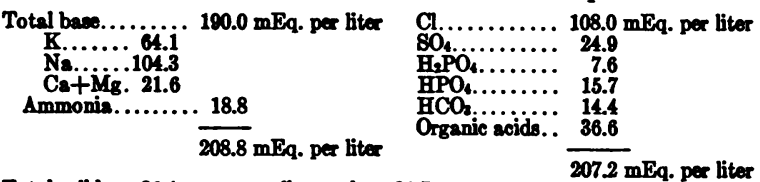

Total solids $=36.1$ grams per biter; ash $=31.7$ per cent.

$207.2 \mathrm{mEq}$. per liter

$\mathrm{NH}_{4}=9.0$ per cent, $\mathrm{K}=30.7$ per cent, $\mathrm{Na}+\mathrm{Ca}+\mathrm{Mg}=60.3$ per cent of total cation.

\begin{tabular}{|c|c|c|c|}
\hline Substance & Concentration & $\begin{array}{c}\text { Specific } \\
\text { gravity } \\
\text { increment }\end{array}$ & Output \\
\hline 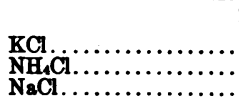 & $\begin{array}{c}m B q . \text { per liter } \\
33.2 \\
9.7 \\
65.1\end{array}$ & $\begin{array}{l}0.00158 \\
0.00016 \\
0.00269\end{array}$ & $\begin{array}{c}\text { grems per liter } \\
2.475 \\
0.519 \\
3.805\end{array}$ \\
\hline $\begin{array}{l}\mathrm{K}_{2} \mathrm{SO}_{4} \ldots \ldots \ldots \ldots \ldots \ldots \\
\left(\mathrm{NH}_{4}\right)_{2} \mathrm{SO}_{4} \ldots \ldots \ldots \ldots \ldots \ldots \\
\mathrm{Na}_{2} \mathrm{SOS}_{4} \ldots \ldots \ldots \ldots \ldots \ldots \ldots\end{array}$ & $\begin{array}{r}7.7 \\
2.2 \\
15.0\end{array}$ & $\begin{array}{l}0.00054 \\
0.00009 \\
0.00096\end{array}$ & $\begin{array}{l}0.671 \\
0.145 \\
1.065\end{array}$ \\
\hline $\begin{array}{l}\mathrm{KH}_{2} \mathrm{PO}_{4} \ldots \ldots \ldots \ldots \ldots \\
\left(\mathrm{NH}_{4}\right) \mathrm{H}_{2} \mathrm{PO}_{4} \ldots \ldots \ldots \ldots \ldots \\
\mathrm{NaH}_{2} \mathrm{PO}_{4} \ldots \ldots \ldots \ldots \ldots \ldots\end{array}$ & $\begin{array}{l}2.3 \\
0.7 \\
4.6\end{array}$ & $\begin{array}{l}0.00022 \\
0.00005 \\
0.00041\end{array}$ & $\begin{array}{l}0.313 \\
0.081 \\
0.552\end{array}$ \\
\hline $\begin{array}{l}\mathrm{K}_{2} \mathrm{HPO}_{4} \ldots \ldots \ldots \ldots \ldots \\
\left.\mathrm{NH}_{4}\right)_{2} \mathrm{HPO}_{4} \ldots \ldots \ldots \ldots \ldots \\
\mathrm{Na}_{2} \mathrm{HPO}_{4} \ldots \ldots \ldots \ldots \ldots \ldots \\
\end{array}$ & $\begin{array}{l}4.8 \\
1.4 \\
9.5\end{array}$ & $\begin{array}{l}0.00034 \\
0.00005 \\
0.00064\end{array}$ & $\begin{array}{l}0.418 \\
0.093 \\
0.675\end{array}$ \\
\hline 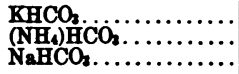 & $\begin{array}{l}4.4 \\
1.3 \\
8.7\end{array}$ & $\begin{array}{l}0.00029 \\
0.00006 \\
0.00053\end{array}$ & $\begin{array}{l}0.440 \\
0.103 \\
0.731\end{array}$ \\
\hline
\end{tabular}

Sum of determined inorganic solids........................... 12.086

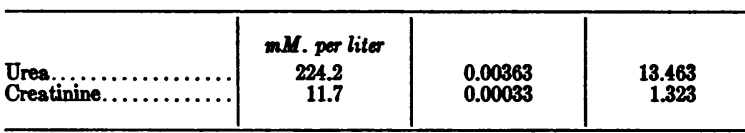

Sum of determined organic solids.......................... 14.786 \begin{tabular}{l|l|r}
\hline Total................. & 0.01257 & 26.872 \\
\hline
\end{tabular}

Specific gravity determined $=\frac{0.0126}{1.0145-0.8982} \times 100=77.3$ per cent Solids determined $=\frac{26.9}{36.1} \times 100=74.5$ per cent 24-Hour output:

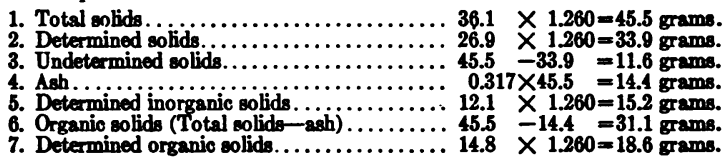

corresponding values calculated from the total solid and ash determinations. An example of the calculation is given in Table VIII and the data for all of the urines in this series are summarized in Table IX.

The data of Table IX show the following relationships between the determined fraction of specific gravity and the determined solid constituents of the urine:

(1) The per cent of specific gravity accounted for by the major constituents of urine is a value 
TABLE IX

Percentage of specific gravity and total organic and inorganic solids determined by analysis of nine normal urines

\begin{tabular}{|c|c|c|c|c|c|c|c|c|c|c|c|c|c|c|c|}
\hline$\underset{\text { ject }}{\text { Sub- }}$ & Date & $\begin{array}{l}\text { 24- } \\
\text { Hour } \\
\text { vol- } \\
\text { ume }\end{array}$ & $\begin{array}{c}\text { Specific } \\
\text { gravity } \\
\text { incre- } \\
\text { ment } \\
\text { ob- } \\
\text { served }\end{array}$ & $\begin{array}{l}\text { Specific } \\
\text { gravity } \\
\text { incre- } \\
\text { ment } \\
\text { calcu- } \\
\text { lated }\end{array}$ & $\begin{array}{c}\text { Per } \\
\text { cent } \\
\text { specific } \\
\text { gravity } \\
\text { deter- } \\
\text { mined }\end{array}$ & $\begin{array}{c}\text { Total } \\
\text { solids } \\
\text { output }\end{array}$ & $\begin{array}{l}\text { Deter- } \\
\text { mined } \\
\text { solids } \\
\text { output }\end{array}$ & $\begin{array}{l}\text { Per } \\
\text { cent } \\
\text { deter- } \\
\text { mined }\end{array}$ & $\begin{array}{l}\text { Ash } \\
\text { per } \\
\text { cent } \\
\text { of } \\
\text { total } \\
\text { solids }\end{array}$ & $\begin{array}{c}\text { Ash } \\
\text { output }\end{array}$ & $\begin{array}{c}\text { Deter- } \\
\text { mined } \\
\text { inor- } \\
\text { ganic } \\
\text { solids } \\
\text { output }\end{array}$ & $\begin{array}{l}\text { Inor- } \\
\text { ganic } \\
\text { solids } \\
\text { per } \\
\text { cent of } \\
\text { ash }\end{array}$ & $\begin{array}{c}\text { Organic } \\
\text { solids } \\
\text { (total } \\
\text { solids } \\
\text {-ash) } \\
\text { output }\end{array}$ & $\begin{array}{c}\text { Deter- } \\
\text { mined } \\
\text { or- } \\
\text { ganic } \\
\text { solids } \\
\text { output }\end{array}$ & $\begin{array}{c}\text { Per } \\
\text { cent } \\
\text { organic } \\
\text { solids } \\
\text { deter- } \\
\text { mined }\end{array}$ \\
\hline & & $c c$. & & & & grams & grams & & & grams & grams & & grams & grams & \\
\hline
\end{tabular}

"High" protein diet

\begin{tabular}{|c|c|c|c|c|c|c|c|c|c|c|c|c|c|c|c|}
\hline $\begin{array}{l}\mathbf{M} \\
\mathbf{L} \\
\mathbf{B} \\
\mathbf{K}\end{array}$ & $\begin{array}{l}\text { April 17 } \\
\text { April 18 } \\
\text { May 19 } \\
\text { May 23 } \\
\text { Average }\end{array}$ & \begin{tabular}{|l|}
1770 \\
1585 \\
1520 \\
1445 \\
\end{tabular} & $\begin{array}{l}0.0167 \\
0.0176 \\
0.0200 \\
0.0200\end{array}$ & $\mid \begin{array}{l}0.01436 \\
0.01489 \\
0.01614 \\
0.01568\end{array}$ & $\begin{array}{l}86.0 \\
84.6 \\
80.7 \\
78.4 \\
82.4\end{array}$ & $\begin{array}{l}68.1 \\
65.8 \\
72.4 \\
68.8\end{array}$ & $\begin{array}{l}\mathbf{5 5 . 8} \\
\mathbf{5 3 . 2} \\
\mathbf{5 7 . 0} \\
\mathbf{5 3 . 5}\end{array}$ & $\begin{array}{l}82.0 \\
80.9 \\
78.7 \\
77.8 \\
79.9\end{array}$ & $\begin{array}{l}31.8 \\
29.8 \\
27.2 \\
26.1\end{array}$ & $\begin{array}{l}21.7 \\
19.6 \\
19.7 \\
18.0\end{array}$ & $\begin{array}{l}23.0 \\
20.4 \\
20.5 \\
18.6\end{array}$ & $\begin{array}{l}106.0 \\
104.1 \\
104.1 \\
103.3 \\
104.4\end{array}$ & $\begin{array}{l}46.4 \\
46.2 \\
52.7 \\
50.8\end{array}$ & $\begin{array}{l}32.8 \\
32.8 \\
36.4 \\
34.8\end{array}$ & $\begin{array}{l}70.7 \\
71.0 \\
69.1 \\
68.5 \\
69.8\end{array}$ \\
\hline
\end{tabular}

"Low" protein diet

\begin{tabular}{|c|c|c|c|c|c|c|c|c|c|c|c|c|c|c|c|}
\hline $\begin{array}{l}\mathbf{L} \\
\mathbf{L} \\
\mathbf{M} \\
\mathbf{B} \\
\mathbf{K}\end{array}$ & $\begin{array}{l}\text { April 24 } \\
\text { April 25 } \\
\text { April 28 } \\
\text { May 25 } \\
\text { June 1 } \\
\text { Average }\end{array}$ & \begin{tabular}{r|}
1300 \\
1430 \\
1320 \\
1260 \\
960
\end{tabular} & $\begin{array}{l}0.0155 \\
0.0144 \\
0.0157 \\
0.0163 \\
0.0216\end{array}$ & $\mid \begin{array}{l}0.01094 \\
0.01151 \\
0.01213 \\
0.01260 \\
0.01645\end{array}$ & $\begin{array}{l}70.6 \\
79.9 \\
77.2 \\
77.3 \\
76.2 \\
76.2\end{array}$ & $\begin{array}{l}41.7 \\
43.7 \\
44.3 \\
45.5 \\
47.7\end{array}$ & $\begin{array}{l}30.4 \\
33.2 \\
34.7 \\
33.9 \\
35.1\end{array}$ & $\begin{array}{l}72.9 \\
76.0 \\
78.4 \\
74.5 \\
73.6 \\
75.1\end{array}$ & $\begin{array}{l}32.2 \\
35.4 \\
33.6 \\
31.7 \\
30.7\end{array}$ & $\begin{array}{l}13.4 \\
15.5 \\
14.9 \\
14.4 \\
14.6\end{array}$ & $\begin{array}{l}13.4 \\
16.4 \\
15.2 \\
15.2 \\
14.3\end{array}$ & $\begin{array}{r}100.0 \\
105.8 \\
102.0 \\
105.6 \\
98.0 \\
102.3\end{array}$ & $\begin{array}{l}28.3 \\
28.2 \\
29.4 \\
31.1 \\
33.1\end{array}$ & $\begin{array}{l}17.0 \\
16.7 \\
19.7 \\
18.6 \\
20.9\end{array}$ & $\begin{array}{l}60.1 \\
59.2 \\
67.0 \\
59.8 \\
63.2 \\
61.9\end{array}$ \\
\hline
\end{tabular}

almost identical with the per cent of total solids which these constituents comprise. There is, therefore, present in urine a very appreciable quantity of solid matter, not ordinarily determined by analysis, but probably sufficient to account for the remainder of the specific gravity if its composition and the specific gravity contributions of the component substances were known.

(2) The determined inorganic solids include all compounds present in sufficiently high concentration to have a significant effect either on specific gravity or on total solid content. The calculated acid-base balances serve as a check on these analyses. As a further check, the 24-hour output of inorganic substances is found to be 98 to 106 per cent of the ash content of the urines, as determined by dry ashing of the residues obtained in the total solid determination. Since this method of ashing produces little change in the composition of these salts, ${ }^{3}$ this agreement indicates that the inorganic

\footnotetext{
${ }^{3}$ Dry ashing will not appreciably affect alkali or alkaline earth chlorides and sulfates. There will be some loss of water from phosphates with formation of metaphosphates and decomposition or volatilization of ammonium salts. Salts of organic acids (which have not been included in calculating the total output of inorganic solids) will be converted to carbonate or bicarbonate and the cations will largely recombine with the anions previously held by ammonia. The net result is a relatively slight
}

constituents have been practically completely determined. The undetermined solid is, therefore, organic in nature.

(3) Urea and creatinine account for only 60 to 70 per cent of the total organic matter (total solids-ash). Approximately 30 to 40 per cent of the organic constituents are substances not commonly determined in urine analyses and they may quite readily account for the 10 to 30 per cent of undetermined specific gravity.

(4) The absolute amount of undetermined organic solids is 10 to 15 grams in the 24-hour urines, slightly higher with high protein intake (Table X).

Direct study of this 10 to 15 grams would necessitate the estimation of a great number of substances excreted in the urine in amounts varying from a few milligrams to a gram or more per day. Such analyses would be impractical and even impossible on a single 24-hour specimen, consequently only the general nature of the undetermined fraction will be discussed. Table $\mathrm{X}$ summarizes the data for this fraction from the series of urines presented in Table IX.

One large group of compounds, the organic

change in weight during the ashing so that the ash content of a urine may be used as a fairly accurate index of the mineral salts present. 
acids, has been determined in all of the analyses and is recorded in Tables $\mathrm{V}$ and $\mathrm{X}$. This analysis is essential in calculating the acid-base balance but the contribution of organic acids to specific gravity has not been calculated since the individual organic acids are not sufficiently well known to make possible the use of an accurate specific gravity factor.

Of the acids determined collectively as organic acids, uric, hippuric, and citric, are known to occur in appreciable amounts. Of these, only uric acid has been determined, and its contribution to specific gravity cannot be estimated since its physical state in urine is not known, it frequently being present in concentration greater than its true solubility in water either as free acid or as urate (36). Hippuric acid is found in appreciable amounts $(0.8$ to 1.9 grams daily output $(17,25))$ and citric acid may be excreted in amounts from 0.2 to 1.0 gram daily $(8,34)$. However, the excretion of these known acids can rarely exceed 3.0 grams per day, which is about $16 \mathrm{mEq}$. or $1 / 3$ to $1 / 2$ of the total organic acid excretion determined by the method of Van Slyke and Palmer (37). If the unknown acids have about the same average equivalent weight as these three, the organic acid fraction could well amount to 6 to 10 grams per day, or about half of the undetermined solids.

A very rough idea of the general effect of organic acids on specific gravity may be calculated from the density data of the International Critical Tables. As sodium salts, these acids have specific gravity factors of about 0.004 to 0.009 per 100 $\mathrm{mEq}$. per liter, averaging about 0.006 . This would definitely place them as comparable to the inorganic salts in their effect on specific gravity (cf. Table I). Assuming the urinary organic acids to behave in a similar manner, the $10 \mathrm{mEq}$. per liter to $100 \mathrm{mEq}$. per liter present might total 0.0006 to 0.006 in specific gravity units, which accounts for about $1 / 2$ of the undetermined fraction of specific gravity.

The fractions of sulphur designated as ethereal and neutral sulphur are listed in Table $X$. The former group contains sulphuric acid conjugated with phenolic compounds such as phenol, indoxyl, skatoxyl, p-cresol, and possibly others such as pyrocatechol and hydroquinone, some of which may be weak enough acids to be at least partially determined in the organic acid fraction. The neut- ral sulphur is present in a wide variety of compounds such as cystine, thiocyanates, taurine derivatives, oxyproteic acids, etc., which are largely endogenous.

While some ethereal compounds of phosphoric acid are present in urine, the amount is so small as to comprise 5 per cent or less of the total phosphorus $(30,46)$. This has been verified in some of the urines studied and the amount of phosphorus represented by these compounds has been neglected.

Small amounts of fermentable carbohydrate are present even in normal urine but the total reducing power of urine is probably largely due to noncarbohydrate substances. Pigments are constantly present, about $75 \mathrm{mgm}$. being excreted daily (12). It is obviously impractical to assign specific gravity factors to these and the multitude of other substances which have been found in urine.

From the data of Table X, the 24-hour output of undetermined $\mathrm{C}, \mathrm{N}$ and $\mathrm{S}$ can be compared with the output of undetermined solid. Uric acid was determined in all of these urines but was grouped with the organic acids which were not considered in calculating the specific gravity. Carbon makes up about 35 to 44 per cent of the weight, nitrogen 5 to 10 per cent, neutral sulphur 0.5 to 1.0 per cent and ethereal sulphur 0.3 to 7 per cent. This

TABLE $X$

Comparison of 24-hour output and composition of total and of undetermined solids

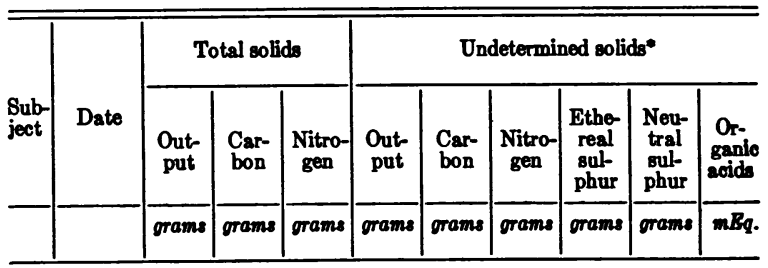

"High" protein diet

\begin{tabular}{l|l|l|l|l|l|l|l|l|l|l}
\hline M & April 17 & 68.1 & 11.30 & 16.66 & 12.3 & 4.30 & 0.97 & 0.034 & 0.085 & 37.2 \\
L & April 18 & 65.8 & 11.19 & 16.44 & 12.6 & 4.23 & 0.66 & 0.056 & 0.087 & 40.0 \\
B & May 19 & 72.4 & 13.42 & 18.42 & 15.4 & 5.71 & 1.04 & 0.085 & 0.078 & 55.5 \\
K & May 23 & 68.8 & 13.72 & 17.78 & 15.3 & 6.32 & 1.18 & 0.072 & 0.084 & 56.0 \\
\hline \multicolumn{6}{c}{ "Low" protein diet }
\end{tabular}

\begin{tabular}{l|l|l|l|l|l|l|l|l|l|l}
\hline L & April 24 & 41.7 & 8.07 & 8.68 & 11.3 & 4.13 & 0.62 & 0.043 & 0.092 & 36.4 \\
L & April 25 & 43.7 & 8.04 & 8.62 & 10.5 & 4.09 & 0.64 & 0.046 & 0.096 & 35.9 \\
M & April 28 & 44.3 & 8.11 & 9.37 & 9.6 & 4.14 & 0.93 & 0.035 & 0.094 & 34.9 \\
B & May 25 & 45.5 & 8.78 & 9.89 & 11.6 & 4.45 & 1.02 & 0.067 & 0.095 & 46.1 \\
K & June 1 & 47.7 & 9.33 & 10.88 & 12.6 & 4.72 & 1.02 & 0.091 & 0.074 & 41.3 \\
\hline
\end{tabular}

* Ethereal sulphur, neutral sulphur and organic acids have been considered entirely with the undetermined fraction of total solids. 
corresponds to an atomic ratio of one atom of sulphur for 10 to 18 atoms of nitrogen and 73 to 107 atoms of carbon." Such a calculation is obviously of no value in determining the composition of any single constituent of the undetermined organic fraction nor is it useful in calculating a specific gravity factor for the unknown fraction. It does, however, permit the following comments:

(1) The undetermined fraction as a whole contains a smaller percentage of nitrogen than if it were composed entirely of protein degradation products. If organic acids, which probably contain little or no nitrogen make up one-half or more of this fraction, the remainder might well approach the composition of protein fairly closely.

(2) Since sulphur makes up only about 1 to 1.5 per cent of the undetermined solid, and the known sulphur-containing compounds in the urine have a relatively high percentage of this element, the actual weight of these compounds must be small.

(3) The percentage composition of the undetermined fraction in the 4 subjects studied on both low and high protein diets is remarkably constant. The absolute quantity excreted daily is only slightly higher on the latter regime. This slight increase may easily be due to the greater excretion of organic acids. These facts indicate quite strongly that the undetermined substances are largely endogenous.

Dialysis of urine through cellophane membranes gives an indication of the molecular size of the substances present. When dialyzed against a confined volume of water, all of the substances analyzed are found to be freely diffusible. When dialyzed against running water until the dialysate is free of chloride, $100 \mathrm{cc}$. of a urine originally containing 1.13 grams of nitrogen and 5.7 grams of total solid contained only $2.9 \mathrm{mgm}$. of nitrogen and $38 \mathrm{mgm}$. of solid. The specific gravity was the same as that of water within the limit of error

4 If the uric acid is not included in the undetermined fraction, the undetermined solid is reduced by 0.5 to 0.8 gram but the percentage composition and empirical formula are not changed significantly (carbon 33 to 40 per cent, nitrogen 4 to 9 per cent, neutral sulphur 0.6 to 1.1 per cent and ethereal sulphur 0.3 to 0.8 per cent, corresponding to an atomic ratio of 1 sulphur to 7 to 14 nitrogen and 70 to 103 carbon).
TABLE XI

Calculation of specific gravity factor for urdetermined fractions of organic solids $(A)$, and comparison of these factors with those of known substances in urine $(B)$

(A)

\begin{tabular}{c|c|c|c}
\hline \hline Subject & $\begin{array}{c}\text { Solids } \\
\text { undetermined }\end{array}$ & $\begin{array}{c}\text { Specific } \\
\text { gravity } \\
\text { undetermined }\end{array}$ & Factor \\
\cline { 2 - 3 } & grams per liter & & $\begin{array}{c}\text { effect 1 gram } \\
\text { per liter }\end{array}$ \\
\hline \multicolumn{3}{c}{110 Gram protein diet } \\
B & 13.1 & 0.0040 & 0.00031 \\
B & 10.2 & 0.0039 & 0.00038 \\
K & 14.9 & 0.0048 & 0.00032 \\
M & 10.7 & 0.0044 & 0.00041 \\
L & 6.9 & 0.0024 & 0.00035 \\
& 8.0 & 0.0028 & 0.00035 \\
\hline \multicolumn{3}{c}{ Average } & 0.00035 \\
\hline
\end{tabular}

50 Gram protein diet

\begin{tabular}{c|r|r|r}
\hline B & 9.2 & 0.0037 & 0.00040 \\
B & 8.9 & 0.0035 & 0.00039 \\
K & 13.1 & 0.0050 & 0.00038 \\
K & 13.0 & 0.0052 & 0.00040 \\
M & 7.2 & 0.0036 & 0.00050 \\
L & 8.7 & 0.0046 & 0.00053 \\
L & 7.3 & 0.0030 & 0.00041 \\
\hline \multicolumn{3}{|c}{ Average } & 0.00043 \\
\hline \multicolumn{2}{c}{ Combined average } & 0.00039 \\
\hline
\end{tabular}

(B)

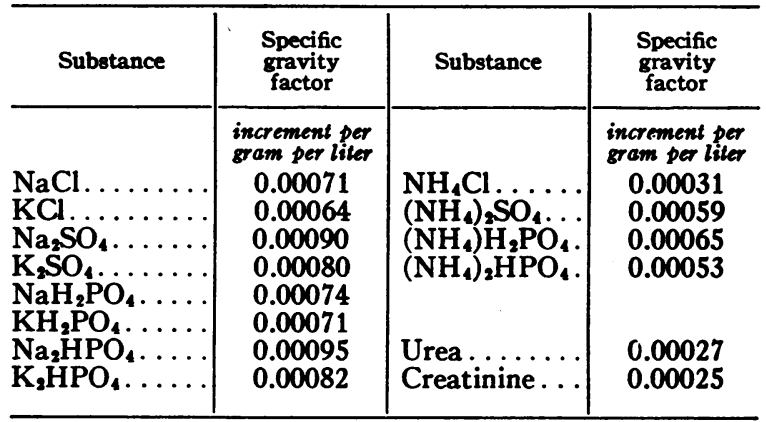

of determination. From these two experiments it is evident that normal urine contains only inappreciable quantities of true colloidal or nondialyzable substances. Consequently, such compounds cannot contribute significantly to the undetermined specific gravity or to the total solids. What little is present is probably mucus or cellular elements derived from the urinary passages plus a small amount of pigment. 
The undetermined substances of the urine may, therefore, be characterized as (1) organic compounds, (2) of relatively low molecular weight (dialyzable), (3) relatively low in nitrogen content, (4) showing only slight variation with diet and (5) sufficient in quantity to account for the undetermined fraction of specific gravity.

The average specific gravity effect per gram of undetermined solid can be obtained from the data presented. This calculation was carried out in thirteen instances and the results are tabulated in Table XI- $A$. In Table XI- $B$ the increments per gram of the determined substances in urine are shown for comparison. The latter fall in three distinct groups: the inorganic salts of $\mathrm{Na}$ and $\mathrm{K}$ having the greatest effect per. gram, urea and creatinine the smallest, and the ammonium inorganic salts intermediate. The undetermined solids exert an effect closest to the organic substances (urea and creatinine), which is consistent with their organic nature. On the high protein diets the undetermined solids have a slightly higher factor, but the difference is not significant. The constancy of this factor is in keeping with a belief in the relative constancy in composition of the undetermined solids.

\section{Estimation of total solids of urine from specific gravity with a critical evaluation of Häser's and Long's coefficients}

Since the specific gravity of urine is a simple additive function of the concentrations of the individual constituents, there is theoretical justification for the various empirical coefficients proposed for the estimation of the solids of urine from specific gravity. Christison in 1840 (10) seems to have been the first to propose such a coefficient, but it was not until Häser's (21) work (1854) that the method received much attention. ${ }^{5}$ The latter estimated the total urinary solids in grams per liter by multiplying the second and third decimal figures of the specific gravity by 2.33 . Long (29) determined specific gravity to the fourth place by pyknometer and the total solids by an evaporation method which permitted correction for losses due to the ammonia evolved from urine on heating. His coefficient of 0.260 at $25 / 4^{\circ}$ is the one most

\footnotetext{
5 The literature has been reviewed by Blohm (7).
}

frequently used at the present time, and is quoted by Hawk and Bergheim (1937) (22) and Best and Taylor (1939) (5). Long calculated his coefficient by dividing the weight of solids by the last three figures of the specific gravity. He noted, without explanation, that there is more variation in the coefficient at low gravities, a variation due in part to the fact that the solid content is correlated not with the last three figures of specific gravity but with the actual increment of specific gravity above that of water. With lower gravities this correction plays a significant rôle, as is shown in the following example: A urine of 1.0300 gravity using Long's coefficient of 0.260 should contain 78.00 grams of solid per liter. It has been shown experimentally in the early part of this paper that, if such a urine is diluted with water, the specific gravity increment is an inverse linear function of the degree of dilution. Since Long determined $D \frac{25^{\circ}}{4^{\circ}}$, the specific gravity increment in this case is $1.0300-0.9971=0.0329$. If this urine were diluted four-fold with water at $25^{\circ}$, the specific gravity $\frac{25^{\circ}}{4^{\circ}}$ would be $0.9971+\frac{0.0329}{4}=1.0053$, not $1.0000-\frac{0.0300}{4}=1.0075$, as is implied when concentration is expressed as a function of the decimal figures of the specific gravity. Since the total solid in the diluted urine is 19.5 grams per liter, Long's coefficient calculated for this example would be $\frac{19.5}{53}=0.368$. Using the average coefficient of 0.260 for this urine, the estimated solids would be $0.260 \times 53=13.8$ grams per liter, almost 30 per cent low.

Long's coefficient was derived from normal urines, the great majority of which were of high specific gravity (only four of the fifty-two urines studied had specific gravities below 1.015 , ten were between 1.015 and 1.020, the rest above 1.020). With these urines of high gravity, the absolute error is not so significant. With the urines of low gravity frequently obtained in disease, however, Long's coefficient will give values for total solid as much as several hundred per cent in error. This criticism does not apply to the coefficients determined from $D \frac{t^{\circ}}{t^{\circ}}(7)$ since, in these cases, the 
TABLE XII

Calculation of coefficients for estimation of total solid content of urine from observed specific gravity $(A)$, and comparison of these with similar coefficients of individual constituents of urine $(B)$

(A)

\begin{tabular}{c|c|c|c}
\hline \hline Subject & Total solid & $\begin{array}{c}I \\
\text { Specific gravity } \\
\text { increment }\end{array}$ & $\begin{array}{c}\text { Coefficient } \\
\frac{S}{I \times 10,000}\end{array}$ \\
\hline & grams per liter & & \\
\hline & 110 Gram protein diet & \\
\hline B & 55.4 & 0.0227 & 0.244 \\
K & 47.6 & 0.0200 & 0.238 \\
K & 62.3 & 0.0253 & 0.246 \\
M & 47.7 & 0.0200 & 0.239 \\
L & 38.5 & 0.0167 & 0.231 \\
& 41.5 & 0.0176 & 0.236 \\
\hline
\end{tabular}

50 Gram protein diet

\begin{tabular}{c|l|l|l}
\hline $\mathrm{B}$ & 36.1 & 0.0163 & 0.221 \\
$\mathrm{~B}$ & 32.9 & 0.0150 & 0.219 \\
$\mathrm{~K}$ & 49.5 & 0.0216 & 0.229 \\
$\mathrm{~K}$ & 44.7 & 0.0194 & 0.231 \\
$\mathrm{M}$ & 33.5 & 0.0157 & 0.213 \\
$\mathrm{~L}$ & 32.1 & 0.0155 & 0.207 \\
$\mathrm{~L}$ & 30.5 & 0.0144 & 0.212 \\
\hline & & Average & 0.219 \\
\hline
\end{tabular}

(B)

\begin{tabular}{|c|c|c|c|}
\hline Substance & $\frac{\frac{\text { Coefficient }}{S}}{I \times 10,000}$ & Substance & $\frac{\substack{\text { Coefficient } \\
S}}{I \times 10,000}$ \\
\hline 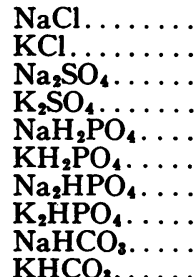 & $\begin{array}{l}0.142 \\
0.157 \\
0.111 \\
0.125 \\
0.134 \\
0.141 \\
0.105 \\
0.122 \\
0.138 \\
0.150\end{array}$ & $\begin{array}{l}\mathrm{NH}_{4} \mathrm{Cl} \ldots \ldots \\
\left(\mathrm{NH}_{4}\right)_{2} \mathrm{SO}_{4} \ldots \\
\left(\mathrm{NH}_{4}\right)_{\mathrm{H}_{2}} \mathrm{PO}_{4} \\
\left(\mathrm{NH}_{4}\right)_{2} \mathrm{HPO}_{4}\end{array}$ & $\begin{array}{l}0.322 \\
0.170 \\
0.153 \\
0.189\end{array}$ \\
\hline
\end{tabular}

specific gravity increment is identical with the decimal figures of the observed specific gravity.

Aside from this theoretical objection to Long's coefficient, there was no great constancy even among urines of high specific gravity, the value ranging from 0.234 to 0.288 , a variation of approximately 20 per cent. Blohm (7) reviewed the subject, introducing a coefficient of $0.218\left(D \frac{15^{\circ}}{15^{\circ}}\right)$ which he claimed yielded better results than any of those previously suggested, but even this gave errors as high as 13 per cent. Addis and Foster (1) went to the other extreme, claiming that there could be no close correlation between the two variables because the specific gravity factors for the substances found in urine differ so widely.

In Table XII are calculated coefficients for thirteen urines. In this same table, for comparison, are given similarly calculated coefficients for the main urinary substances. It is evident that the average coefficient, $0.228\left(D \frac{20^{\circ}}{4^{\circ}}\right)$ is similar to that of Long $\left(0.260 ; D \frac{25^{\circ}}{4^{\circ}}\right)$ and of Blohm $\left(0.218 ; D \frac{15^{\circ}}{15^{\circ}}\right)$ with variations corresponding to those found by the latter. The coefficients derived from urines of subjects on low protein diets are lower than those from the same subjects on high protein diets. This follows naturally and is due to the much larger amount of urea in the latter cases.

The coefficients in Table XII- $B$ are the reciprocals of the factors in Table XI- $B$. Converted to these coefficients, the force of Addis' contention is obvious: there is a wide disparity, the inorganic salts as a class having low coefficients, those for urea and creatinine about two to three times as high, with the salts of ammonia giving intermediate values. Nevertheless, the relative constancy of the pattern of the urine constituents on fixed diets indicates that in these cases the concentration of solids can be predicted fairly accurately with coefficients derived from a sample of the group. Although a greater variation in the coefficient might be expected from urines of subjects on uncontrolled diets, the values found with ten random 24hour specimens have fallen within the extremes of the more carefully controlled series.

\section{DISCUSSION}

Since Folin's study (16) of thirty normal urines in 1905, there have appeared in the literature a number of similar but less complete analyses. As a result, the normal range of excretion of the chief urine constituents is fairly well established for American subjects on usual diets. Despite the wide variations in individuals, there is a definite 
tendency for this group as a whole to deviate from other groups of different dietary habits such as Europeans (32) with higher urea excretion, Filipinos (11) with low urea and salt outputs, and Japanese (24) with high salt excretion.

The analytical data presented in this paper fall within the normal range as given by other authors and the low and high protein intakes, 40 to 50 grams and 100 to 110 grams, respectively, represent about the minimum and maximum encountered in the great majority of random 24-hour diets.

There seem to be no recent data where total urine solid excretion has been determined simultaneously with analyses of the major constituents of the urine. The excretion of undetermined organic solids has been either neglected or given as 2 to 3 grams per 24 hours (31). From the available data on the average excretion of the urinary constituents not analyzed in this study, hippuric, citric and oxalic acids, carbohydrate, amino-acids, purine bases, pigments, volatile fatty acids, cystine, etc., could account for only 3 to 4 grams of solid. Hence, the undetermined organic solid of 10 to 15 grams observed in this series of urines is much higher than that previously assumed to be present. The 24-hour output of undetermined solid has also been determined on 10 additional normal adult subjects of both sexes who were allowed a free choice of diet. The values obtained were the same as for the subjects on the controlled diets, 9 to 15 grams. Organic acids, as has been noted, make up a large part of this solid and the significance of these compounds was not apparent to the earlier investigators.

The assumption that the specific gravity of urine can be accounted for on the basis of the concentration of dissolved substances alone, without recourse to physico-chemical phenomena, has been implied in the work of all of those who have calculated the specific gravity contributions of individual substances. Since this has been shown to be a valid assumption, the available data may be compared with those of Table VII. Our results for the sum of urea and $\mathrm{Cl}$ as $\mathrm{NaCl}$ on the high protein diet are in accord with those of Pepper (35) and Ishizu (24), although the data of these investigators show somewhat greater variation in both urea and chloride, since they are based on urine from subjects on unrestricted diets. In all cases, however, urea and $\mathrm{NaCl}$ account for $1 / 2$ to $3 / 4$ of the specific gravity. On the assumption that specific gravity was determined by urinometer at $D \frac{t^{\circ}}{t^{\circ}}$, and that the average urine $\mathrm{pH}$ was 6.0 , Folin's data (16) may be used to calculate individual specific gravity contributions. The results are almost identical with our high protein data. Urea accounted for an average of 26 per cent, chloride 23 per cent, sulfate 15 per cent, and phosphate 16 per cent of the total. In individual urines 72 to 90 per cent of specific gravity was accounted for by these substances. The data of Concepcion (11) for Filipinos, on the other hand, are comparable with our low protein data. For these groups, urea $+\mathrm{NaCl}$ account for slightly less than $1 / 2$ of the specific gravity.

Our data would seem to invalidate the conclusion of Alving and Van Slyke that the concentration test measures chiefly the ability of the kidney to concentrate mineral salts because of their assumption that these comprise $3 / 4$ of the specific gravity of the urine. Actual measurements show that mineral salts contribute only 50 to 60 per cent of the specific gravity, while urea and other organic constituents make up the remainder. Consequently, the concentration test measures equally the capacity of the kidney to excrete both inorganic and organic substances. A dilute urine in a normal individual is the result of excretion of larger volumes of water with equal reduction of the gravity contributions of salts and organic substances, the specific gravity patterns remaining the same.

Specific gravity is not the only physical property of urine which may be used as an index of the concentration of dissolved solids. Cryoscopy was introduced in 1897 by von Koranyi (26) and carefully studied by Kövesi and Roth-Schultz (27). Since the depression of the freezing point of water is dependent on the number of dissolved particles, rather than their chemical nature, this method might have some advantage over specific gravity as a measure of total solid, but ionization of electrolytes is a disturbing factor. Von Hahn (20) has correlated surface tension with specific gravity so that this property might also be used as a measure of concentration. Blohm (7) introduced a refractometric method, which is probably the most accu- 
rate of any of the physical measures of total solid concentration, and gives values within 5 per cent of those determined by analysis. Its accuracy rests on the fact that, whereas the specific gravity factors of the various urinary constituents range from 0.9 to 3.6 times the factor of urea (concentration expressed in grams per liter) the " refractometric indices" of the same constituents range from 0.8 to 2.0 times that of urea, most of them being 1.1 to 1.4 times greater. Variations in concentrations of individual constituents therefore produce smaller changes in the refractometric index than they do in the specific gravity. Like the cryoscopic method, however, this procedure requires apparatus not commonly available.

All of these attempts to determine total solid output by a simple measurement of some physical property have been devised in order to test the function of the kidney in the excretion of solids. The colligative properties of a solution, vapor pressure, osmotic pressure, and freezing point depression are not directly proportional to solid concentration because of the ionization of electrolytes. The specific gravity test is the simplest and most widely used at present. Despite its widespread use the exact relationship between it and the composition of the urine has never been systematically studied. The results obtained here indicate that specific gravity measures concentration roughly in the same manner as the colligative properties, i.e., with electrolytes having relatively greater effect per unit concentration than the organic substances.

Whether the low specific gravity encountered in kidney disease is simply the result of dilution, with preservation of the normal pattern of specific gravity contributions, or whether there is greater impairment in ability to concentrate some substances than others, must await similar analyses of pathological urines which are in progress.

\section{SUM MARY}

1. Evidence is presented that the specific gravity of a complex dilute solution of inorganic and organic substances can be calculated with considerable accuracy. Electrolytes have a greater effect on specific gravity than organic solutes for equivalent concentrations. The effect of electrolytes is approximately a summation of the specific gravity effects of the individual ions.
2. The specific gravity of an artificial solution made up of the major substances commonly found in normal urine is the sum of the specific gravity effects of the individual substances.

3. The specific gravity of urine is a simple additive function of the concentration of its individual solutes.

4. Forty-eight 24-hour urines from 6 subjects with normal renal function have been analyzed for chloride, sulfate, phosphate, bicarbonate, urea, creatinine, $\mathrm{pH}$, and total solids, and the specific gravity contributions of the inorganic salts, urea, and creatinine have been calculated. In urine from subjects on a low ( 40 to 50 grams) protein diet, urea acounts for 15 to 20 per cent, chlorides for 25 to 30 per cent, sulfate and phosphate together 15 to 25 per cent, bicarbonate 1 to 5 per cent, and creatinine 1 to 2 per cent of the observed specific gravity. On a high (100 to 110 grams) protein diet, urea, sulfate, and phosphate contribute a slightly higher proportion to the specific gravity. On the lower protein diets, 70 to 80 per cent, on the higher protein diets, 80 to 90 per cent of the specific gravity is accounted for by all the substances measured.

5. The undetermined fraction of specific gravity comprises 10 to 30 per cent of the observed value and in the same urines the excretion of undetermined solids amounts to 10 to 15 grams daily or from 10 to 30 per cent of the total solids. The undetermined solid is composed of organic substances. This fraction is relatively low in nitrogen, of small molecular size (dialyzable) and is largely endogenous in origin. Approximately onehalf of this fraction is made up of organic acids.

6. The various coefficients proposed for estimation of total solids in urine from specific gravity are valid only for urines of the same relative composition, since the coefficients of organic and inorganic solutes differ by 200 to 300 per cent. Consequently, in normal subjects on fixed diets, the solid content can be estimated quite accurately from specific gravity by means of coefficients. In random urines, on the other hand, the variation in composition is sufficient to make the use of coefficients too inaccurate for exact analytical use.

\section{BIBLIOGRAPHY}

1. Addis, T., and Foster, M. G., The specific gravity of the urine. Arch. Int. Med., 1922, 30, 555. 
2. Addis, T., and Shevky, M. C., A test of the capacity of the kidneys to produce urine of high specific gravity. Arch. Int. Med., 1922, 30, 559.

3. Albarran, J., Exploration des Fonctions Rénales. Etude Médico-chirurgicale. Masson et Cie, Paris, 1905, p. 52.

4. Alving, A. S., and Van Slyke, D. D., The significance of concentration and dilution tests in Bright's disease. J. Clin. Invest., 1934, 13, 969.

5. Best, C. H., and Taylor, N. B., The Physiological Basis of Medical Practice. Wm. Wood, Baltimore, 1939, 2nd ed.

6. Blackall, J., Observations on the Nature and Cure of Dropsy and Particularly on the Presence of the Coagulable Part of the Blood in Dropsical Urine. James Webster, Philadelphia, 1820, 1st American ed., from 3rd English ed.

7. Blohm, G. J., Om bestämmandet af halten fasta beståndsdelar i urinen. Upsala läkaref. förh., 1918, 23, 283.

8. Boothby, W. M., and Adams, M., The occurrence of citric acid in urine and body fluids. Am. J. Physiol., 1934, 107, 471.

9. Bright, R., Reports of Medical Cases Selected with a View of Illustrating the Symptoms and Cure of Diseases by a Reference to Morbid Anatomy. London, 1827. (Published in "Original Papers of Richard Bright on Renal Disease." Oxford University Press, London, 1937.)

10. Christison, R., On Granular Degeneration of the Kidneys and Its Connection with Dropsy, Inflammation, and other Diseases (Dunglison's Am. Med. Library). A. Waldie, Philadelphia, 1839.

11. Concepcion, Isabelo, Analysis of normal Filipino urine. Philippine J. Sc., Sec. A, 1918, 13, 347.

12. Drabkin, D. L., The normal urinary pigment. A new method for its extraction. J. Biol. Chem. (Proc.), 1927, 74, xv.

13. Ebstein, E., Die klinische Geschichte des Urometers. Internat. Beitg. z. Gesch. d. Med. 83. Festschrift Max Neuburger gewidmet Wein., 1928.

14. Fishberg, A. M., Hypertension and Nephritis. Lea and Febiger, Philadelphia, 1939, 4th ed.

15. Flosdorf, E. W., and Mudd, S., An improved procedure and apparatus for preservation of sera, microorganisms, and other substances. The cryochemprocess. J. Immunol., 1938, 34, 469.

16. Folin, O., Approximately complete analyses of thirty "normal" urines. Am. J. Physiol., 1905, 13, 45.

17. Folin, O., and Flanders, F. F., A new method for the determination of hippuric acid in urine. J. Biol. Chem., 1912, 11, 257.

18. Gamble, J. L., Carbonic acid and bicarbonate in urine. J. Biol. Chem., 1922, 51, 295.

19. Gamble, J. L., McKhann, C. F., Butler, A. M., and Tuthill, E., An economy of water in renal function referable to urea. Am. J. Physiol., 1934, 109, 139.

20. von Hahn, F. V., The relation between the surface tension and the specific gravity of the urine. Biochem. Ztschr., 1926, 178, 245.

21. Häser, F., Archiv. für wissenschaftliche Heilkunde, 1854, 1, 267.

22. Hawk, P. B., and Bergheim, O., Practical Physiological Chemistry. P. Blakiston's Son \& Co., Philadelphia, 1937, 11th ed.

23. Hedinger, and Schlayer, - ., Ueber die Prüfung der Nierentätigkert durch Probemahlzeit. Deutsches Arch. f. klin. Med., 1914, 114, 120.

24. Ishizu, S., Beziehung zwischen dem Spezifischen Gewicht des Harns und den Harnbestandteilen; Untersuchung beim normalen Harn. Jap. J. Dermat. and Urol. (Abst. Section), 1934, 36, 59.

25. Kingsbury, F. B., and Swanson, W. W., The synthesis and elimination of hippuric acid in nephritis; a new renal function test. Arch. Int. Med., 1921, 28, 220.

26. Koranyi, A. von, Physiologische und klinische Untersuchungen über den osmotischen Druck thierischer Flussigkeiten. Ztschr. f. klin. Med., 1897, 33, 1. Idem., 1898, 34, 1.

27. Kovesi, G., and Roth-Schultz, W., Uber Störungen der wassersecernirenden Thätigkeit diffus erkrankter Nieren. Klin. Wchnschr., 1900, 37, 321.

28. Lashmet, F. H., and Newburgh, L. H., An improved concentration test of renal function. J. A. M. A., 1932, 99, 1396.

29. Long, J. H., On the relation of the specific gravity of urine to the solids present. J. Am. Chem. Soc., 1903, 25, 257.

30. Mathison, G. C., The output of organic phosphorus in urine. Biochem. J., 1908, 4, 274.

31. Mathews, A. P., Physiological Chemistry. Williams and Wilkins Co., Baltimore, 1939, 6th ed.

32. McCay, D., Standards of the constituents of the urine and blood and the bearing on the metabolism of Bengalis on the problems of nutrition (Scientific memoirs by officers of medical and sanitary departments of government of India. N. S. No. 34). Superintendent Government Printing, Calcutta, India, 1908.

33. Mosenthal, H. O., Renal function as measured by the elimination of fluids, salt, and nitrogen, and the specific gravity of the urine. Arch. Int. Med., 1915, 16, 733.

34. Östberg, O., Studien über die Zitronensäureausscheidung der Menschenniere in Normalen und Pathologischen Zuständen. Skandinav. Arch. f. Physiol., 1931, 62, 81.

35. Pepper, O. H. P., Studies on the specific gravity of the urine. J. Clin. Invest., 1924, 1, 13. .

36. Peters, J. P., and Van Slyke, D. D., Quantitative Clinical Chemistry, Vol. I, Interpretations. Williams and Wilkins Co., Baltimore, 1931.

37. Peters, J. P., and Van Slyke, D. D., Quantitative Clinical Chemistry, Vol. II, Methods. Williams and Wilkins Co., Baltimore, 1932.

38. Rayer, P. F. D., Traité des Maladies des Reins et des 
Altérations de la Sécrétion Urinaire, étudieés en elles-mêmes et dans leurs Rapports avec les Maladies des Uretères, de la Vessie, de la Prostate, de l'urèthre, etc., avec un Atlas in Folio. Vol. 2. Baillière, Paris, 1840.

39. Rees, G. O., Analysis of the Blood and Urine in Health and Disease. Longman, Brown, Green, and Longmans, London, 1845.

40a. Sendroy, J., Jr., Seelig, S., and Van Slyke, D. D., Studies of acidosis; application of HendersonHasselbach equation to human urine. J. Biol. Chem., 1934, 106, 463.

40b. Sendroy, J., Jr., Seelig, S., and Van Slyke, D. D., Studies of acidosis; carbon dioxide tension and acid-base balance of human urine. J. Biol. Chem., 1934, 106, 479.
41. Valson, C. A., Propriétés Modulaires des Solutions Salines, Considérées au Point de vue des Densités. Compt. Rend. de l'Acad. des Sci., 1871, 73, 441.

42. Volhard, F., Die doppelseitigen hämatogenen Nierenerkrankungen. Julius Springer, Berlin, 1918, p. 60.

43. Weiser, J., and Thelen, H., Beziehung zwischen Dichte und Zusammen setzung des Harnes. Deutsches Arch. f. Klin. Med., 1936, 179, 362.

44. Willis, T., A Study of the Specific Gravity of the Urine. Dissertation. Yale University School of Medicine, 1936.

45. Wright, S. L., and Allison, C. L., The determination of total base. J. Biol. Chem., 1933, 100, 1.

46. Youngburg, G. E., and Pucher, J. W., Analytical methods and observations on the organic phosphorus of the urine. J. Biol. Chem., 1924, 62, 31. 